\title{
Chemical ozone loss in the Arctic vortex in the winter 1995-96: HALOE measurements in conjunction with other observations
}

\author{
R. Müller ${ }^{1}$, J. -U. Grooß ${ }^{1}$, D. S. McKenna ${ }^{1}$, P. J. Crutzen ${ }^{2}$, C. Brühl ${ }^{2}$, J. M. Russell III ${ }^{3}$, L. L. Gordley ${ }^{4}$, \\ J. P. Burrows ${ }^{5}$, A. F. Tuck ${ }^{6}$ \\ ${ }^{1}$ Institute for Stratospheric Chemistry (ICG-1), Forschungszentrum Jülich, Jülich, Germany \\ ${ }^{2}$ Atmospheric Chemistry Department, Max Planck Institute for Chemistry, Mainz, Germany \\ ${ }^{3}$ Hampton University, Hampton, Virginia, USA \\ ${ }^{4}$ NASA Langley Research Center, Hampton, Virginia, USA \\ ${ }^{5}$ Institute for Environmental Physics, University of Bremen, Germany \\ ${ }^{6}$ NOAA Aeronomy Laboratory, Boulder, Colorado, USA
}

Received: 7 July 1997 / Revised: 24 January 1998 / Accepted: 12 May 1998

\begin{abstract}
Severe chemical ozone loss has been detected in the Arctic in the winter and spring of 1995-96 by a variety of methods. Extreme reductions in column ozone due to halogen catalysed chemistry were derived from measurements of the Halogen Occultation Experiment (HALOE) on board the Upper Atmosphere Research Satellite in the Arctic vortex. Here, we discuss further aspects of the HALOE observations in the Arctic over this period. Potential problems, both in the data themselves and in the methodology of the data analysis are considered and the reason for the differences between the Arctic ozone losses deduced from HALOE data version 17 and 18 is analysed. Moreover, it is shown that HALOE measurements in the Arctic in winter and spring 1995-96 compare well with observations by other ground-based and satellite instruments.
\end{abstract}

Key words. Chemical ozone loss (Arctic vortex 1995-96; halogen chemistry).

\section{Introduction}

Since 1989, chemical ozone loss in the Arctic vortex has been inferred from ozonesonde and aircraft measurements (e.g. Hofmann et al., 1989; Proffitt et al., 1990, 1993; Hofmann and Deshler, 1991; Koike et al., 1991; Kyrö et al., 1992; Browell et al., 1993; von der Gathen et al., 1995; Rex et al., 1998a), albeit to a lesser extent than over Antarctica. More recent observations that also included satellite data (Larsen et al., 1994; Manney et al., 1994a, 1996a; Donovan et al., 1995; Bojkov et al.,
1995; Wirth and Renger, 1996; Müller et al., 1996; Goutail et al., 1998a; Rex et al., 1998b) have indicated particularly strong chemical ozone loss in the Arctic vortex for early 1993 and 1995.

Chemical ozone change in the Arctic is difficult to quantify, since dynamical processes cause substantial ozone variations (see e.g. Manney et al., 1994a; von der Gathen et al., 1995; Müller et al., 1996, and references therein). Total ozone is a quantity that is especially problematical in this respect, as it is both subject to significant short term reductions due to high-pressure systems in the troposphere and characterised by a strong seasonal cycle in high latitudes. Climatological values for Northern Hemisphere high-latitude stations show an increase of total ozone between November and March by more than 100 DU (e.g., Hansen et al., 1997).

In March 1996 and 1997, record low values of total ozone were measured in the Arctic vortex (Newman et al., 1997); an observation which triggered further detailed investigations (e.g. GRL, 1997). While for both winters substantial chemical ozone depletion is inferred (e.g. Donovan et al., 1996, 1997; Manney et al., 1996b, 1997; Müller et al., 1997a, b) there is consensus that direct dynamical effects contribute significantly to the unusually low ozone columns observed in March 1997 (Donovan et al., 1997; Manney et al., 1997). Consistent with these findings, the proxy ozone derived from HALOE tracer observations, which reflects the dynamical situation in the absence of chemistry, indicates much less descent (and thus lower total ozone) in the vortex in March 1997 than in March 1996 (Müller et al., 1997a, b).

Here, we focus on the situation in the polar vortex in the Arctic winter and early spring of 1995-96. During this winter, temperatures were both extremely low and more persistently low than usual, if compared to long term records (Manney et al., 1996b; Naujokat and 
Pawson, 1996). This caused frequent polar stratospheric cloud (PSC) formation and subsequent chlorine activation of large vertical extent and uncharacteristically long duration (Hansen and Hoppe, 1996; Santee et al., 1996a; Müller et al., 1997a). Indeed, formation and sedimentation of ice particles as well as dehydration of stratospheric air were observed for the first time in the Arctic vortex in January 1996 (Vöemel et al., 1997; Hintsa et al., 1998). Consistent with the continuing large-scale chlorine activation, anomalously low ozone levels were observed in the vortex throughout the lower stratosphere (Donovan et al., 1996; Manney et al., 1996b; Müller et al., 1997a), large chemical ozone loss rates were derived from ozonesonde observations (Rex et al., 1997), and unusually low ozone columns were observed by ground-based (Hansen et al., 1997; Bojkov et al., 1998; Goutail et al., 1998b) and satellite (Müller et al., 1997a) instruments in the Arctic. Further, total ozone column measurements of the GOME instrument (see later), indicate that the whole stratospheric vortex in March 1996 is characterised by extremely low ozone levels. Moreover, the expected enhancement of ground level UV-B radiation was observed (under clear sky conditions) at two midlatitude stations: Glasgow, $56^{\circ} \mathrm{N}$ (Moseley and MacKie, 1997) and Garmisch-Partenkirchen $47.5^{\circ} \mathrm{N}$ (Seckmeyer et al., 1997); UV-B levels significantly higher than normal for the time of the year were measured during the first days of March 1996.

We concentrate here on the analysis of observations by the Halogen Occultation Experiment (HALOE) (Russell et al., 1993) on the Upper Atmosphere Research Satellite (UARS) inside the Arctic vortex in winter and spring 1995-96. The relationship between an effectively inert trace substance $\left(\mathrm{CH}_{4}\right)$ and chemically more active compounds $\left(\mathrm{HCl}\right.$ and $\left.\mathrm{O}_{3}\right)$ in this data set have been used previously to deduce chlorine activation and chemical ozone loss (Müller et al., 1996, 1997a). The purpose of this contribution is to provide further details of the observations in 1995-96 and to investigate questions that could not be fully discussed in Müller et al. (1997a) in particular the following questions:

1. May the $\mathrm{O}_{3} / \mathrm{CH}_{4}$ relation from the November 1995 HALOE observations be used as a reference for the conditions inside the incipient vortex ?

2. What is the reason for the differences between the Arctic ozone losses deduced from HALOE data version 17 and 18 (Müller et al., 1996, 1997a)?

3. How well do HALOE measurements compare with other observations in the Arctic in winter and spring 1995-96?

\section{Ozone loss in the arctic vortex in 1995-96}

\section{HALOE observations}

The HALOE instrument on UARS measures $\mathrm{O}_{3}, \mathrm{H}_{2} \mathrm{O}$, $\mathrm{NO}_{2}, \mathrm{NO}, \mathrm{HCl}, \mathrm{HF}$, and $\mathrm{CH}_{4}$, usually achieving 15 sunrise and 15 sunset (solar occultation) measurements each day along two approximately constant latitude

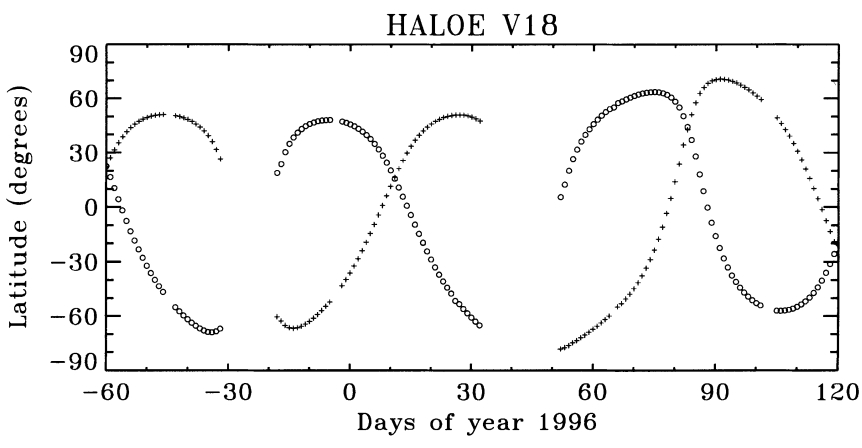

Fig. 1. Latitude coverage of HALOE observations from November 1, 1995 to April 30, 1996. Circles indicate sunrise observations, plus signs sunset observations
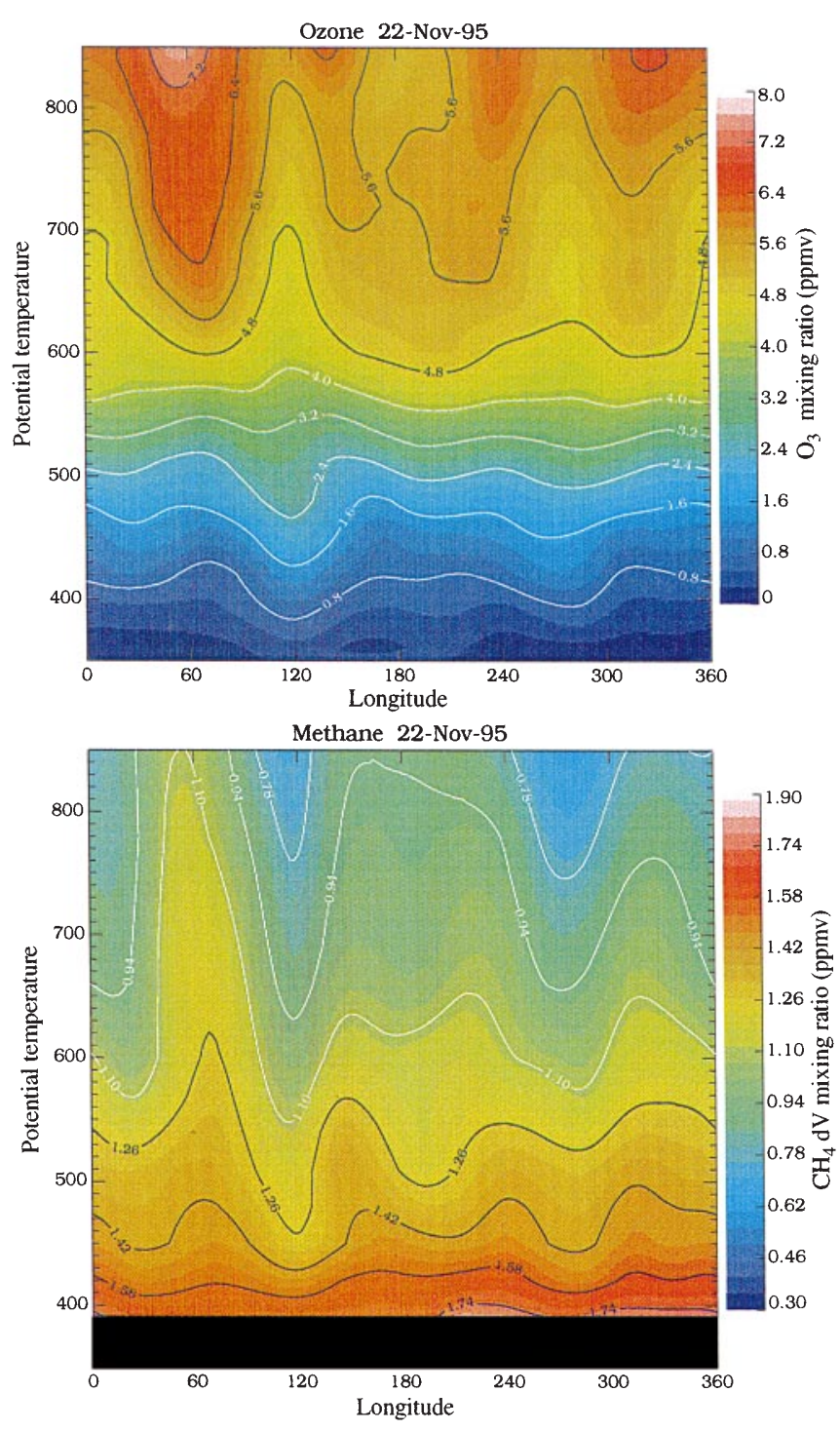

Fig. 2. Observations of the Halogen Occultation Experiment (HAL$\mathrm{OE}$ ) at sunset on November 22, 1995 (uarsday 1533), at $47^{\circ} \mathrm{N} . \mathrm{O}_{3}$ (top panel) and $\mathrm{CH}_{4}$ (bottom panel) mixing ratios, measured by HALOE, are shown versus longitude and potential temperature (as a vertical coordinate). Vortex air is discernible over the whole altitude range at $118^{\circ} \mathrm{E}$. The HALOE data were processed with software version 18 
belts (Russell et al., 1993). Because of the UARS orbit, the location of these latitude belts varies with season. In Fig. 1, the latitude coverage of HALOE in late 1995 and early 1996 is shown. Therefore, regular HALOE measurements inside the Arctic vortex are not available; nevertheless, vortex observations were obtained in January, March, and April 1996. Vortex air was furthermore observed in mid and late November 1995, shortly after the formation of the Arctic vortex. A coherent vortex is formed when the maximum average wind speed at $\approx 450 \mathrm{~K}$ along $\mathrm{PV}$ isolines reaches about $15 \mathrm{~m} \mathrm{~s}^{-1}$ (Nash et al., 1996), which occurred in early November 1995 (Coy et al., 1997).

Compared to mid-latitude air, vortex air is characterised by enhanced potential vorticity (PV) and, due to diabatic descent, substantially lower $\mathrm{CH}_{4}$ mixing ratios. Especially towards the vortex edge, in a region of strong gradients of both PV and tracer mixing ratios,
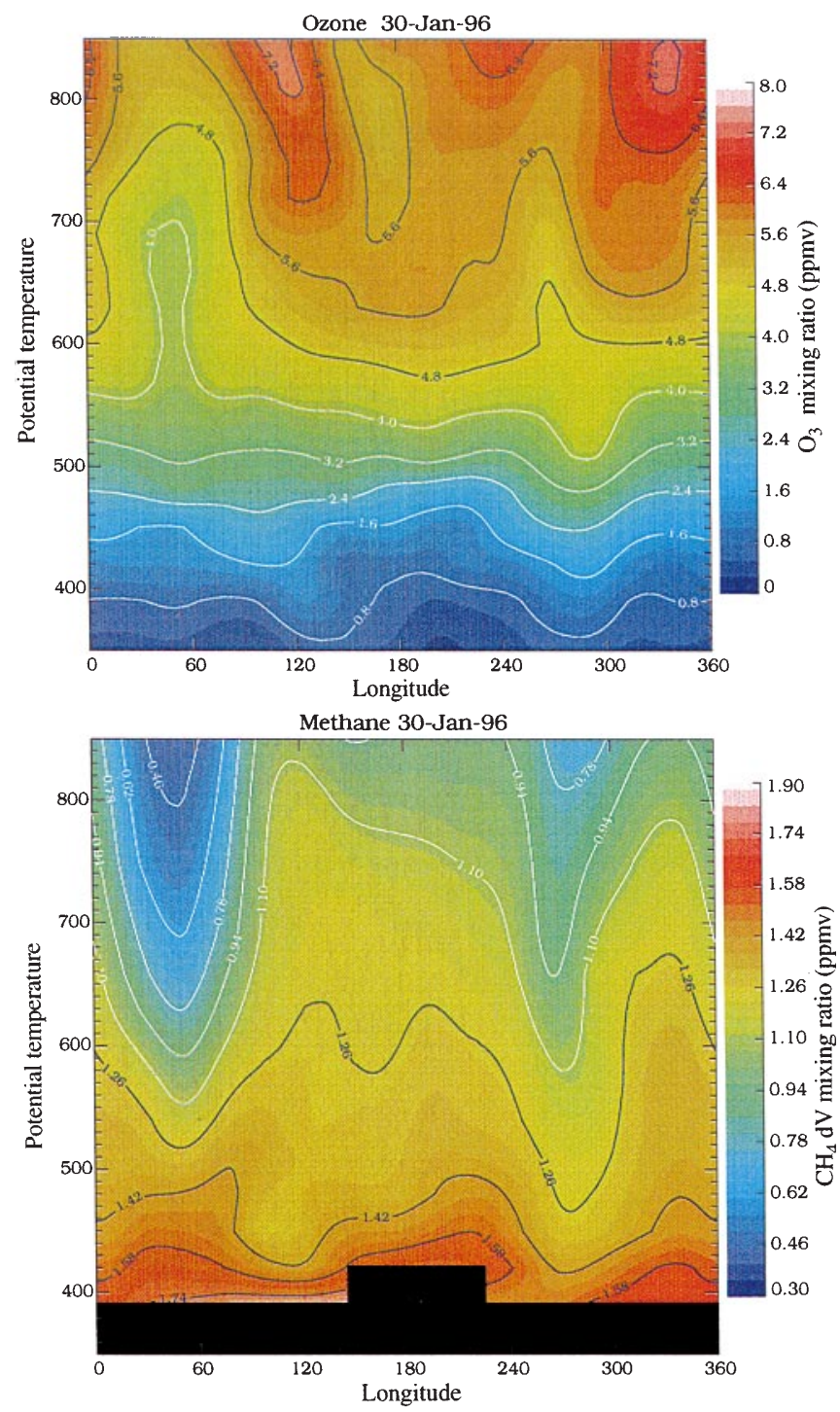

Fig. 3. As Fig. 2 but for sunset observations on January 30, 1996 (uarsday 1602), at $49^{\circ} \mathrm{N}$. Vortex air is discernible over the whole altitude range at $267^{\circ} \mathrm{E}$ however, the resolution of PV computed from meteorological analyses is not sufficient to yield a good correlation with tracer observations, which show more fine scale structure (Fairlie et al., 1997; Tuck and Proffitt, 1998). Here, we use the HALOE tracer $\left(\mathrm{CH}_{4}\right)$ observations to discriminate between mid-latitude and vortex air and discuss PV as a corroborating evidence. Four examples of occasions when HALOE sampled Arctic vortex air in the winter 1995-96 are shown for $\mathrm{CH}_{4}$ and $\mathrm{O}_{3}$ in Fig. 2 for November 22, 1995, at $47^{\circ} \mathrm{N}$, in Fig. 3 for January 30, at $49^{\circ} \mathrm{N}$, in Fig. 4 for March 16 , at $64^{\circ} \mathrm{N}$, and in Fig. 5 for April 1,1996 , at $70^{\circ} \mathrm{N}$. $\mathrm{CH}_{4}$ and $\mathrm{O}_{3}$ mixing ratios are shown versus longitude and potential temperature (as the vertical coordinate). Owing to downward transport through diabatic descent in the vortex, $\mathrm{CH}_{4}$ mixing ratios inside the vortex are lower on a specific isentropic surface than outside. On all four days, vortex air characterised by lower $\mathrm{CH}_{4}$
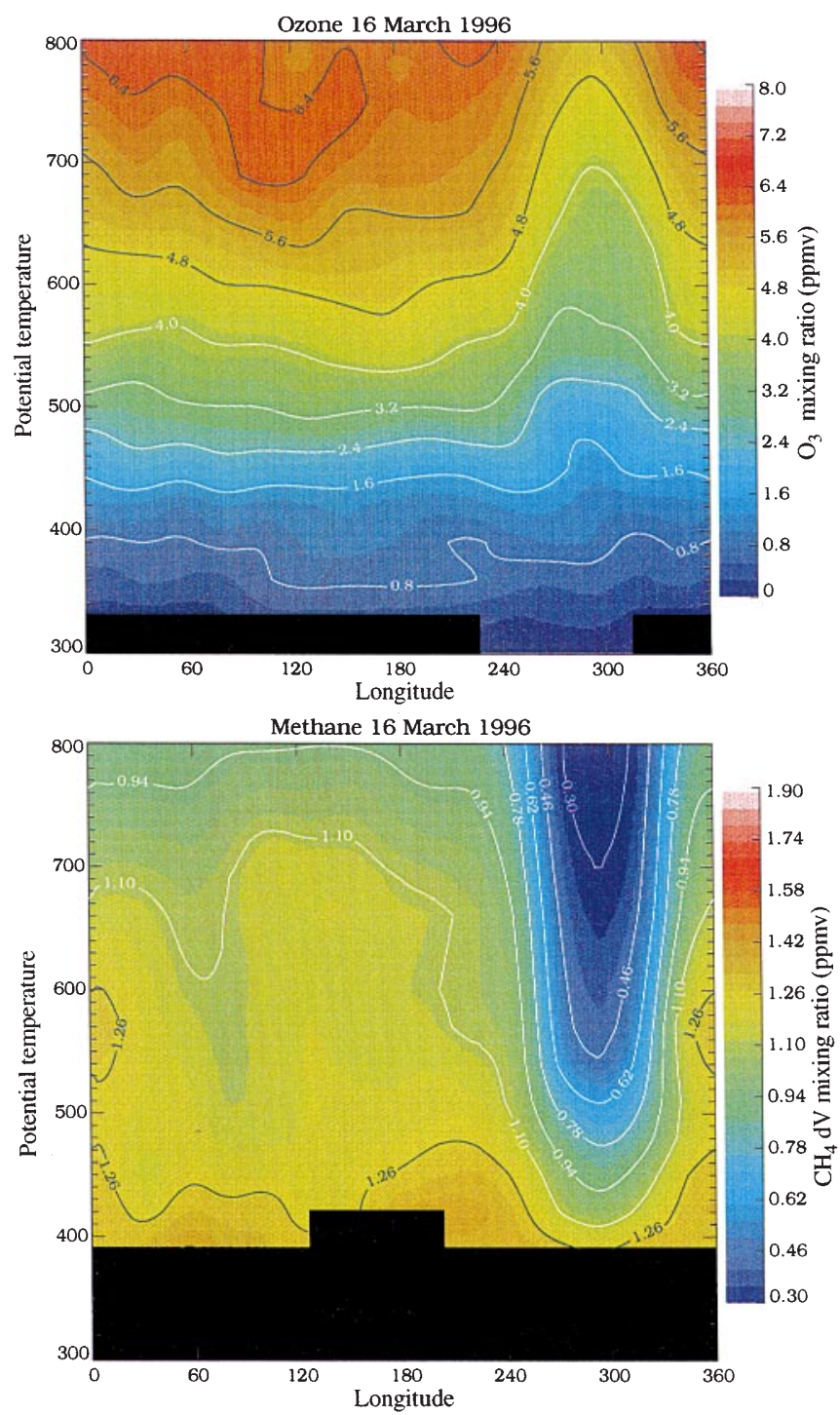

Fig. 4. As Fig. 2 but for sunrise observations on March 16, 1996 (uarsday 1648), at $64^{\circ} \mathrm{N}$. Vortex air is discernible over the whole altitude range at $294^{\circ} \mathrm{E}$ 


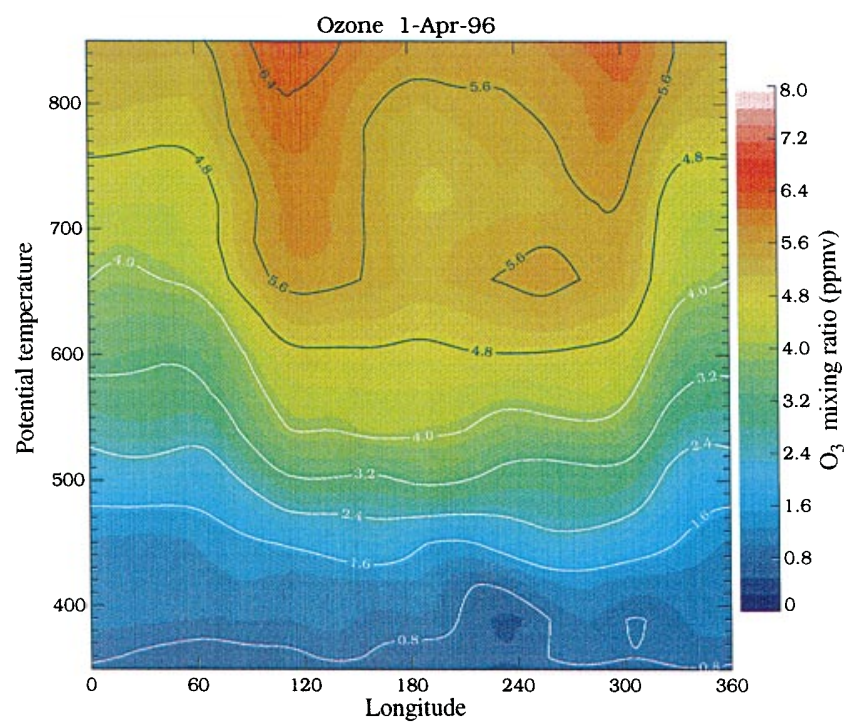

Fig. 5. As Fig. 2 but for sunset observations on April 1, 1996 (uarsday $1664)$, at $70^{\circ} \mathrm{N}$. Vortex air is discernible over the whole altitude range at $8^{\circ} \mathrm{W}-64^{\circ} \mathrm{E}$

mixing ratios is discernible (though not always over the whole altitude range), much as observed in previous years (Müller et al., 1996). To use the relationship between an effectively inert trace substance and chemically more active compounds has been established as a method to discriminate chemical change from large variations due to dynamical processes (e.g., Proffitt et al., 1993; Müller et al., 1996). Compact relationships are expected for species with sufficiently long photochemical lifetimes (Plumb and Ko, 1992). In particular, neglecting mixing across the vortex boundary, an unchanging relationship between ozone and chemically inert tracers (such as $\mathrm{N}_{2} \mathrm{O}, \mathrm{CH}_{4}$ or $\mathrm{HF}$ ) is predicted for the air mass inside the polar vortex, if no chemical ozone loss would occur (Plumb and Ko, 1992). This is actually observed in HALOE measurements of the $\mathrm{O}_{3} /$ $\mathrm{CH}_{4}$ relation between November 1995 and late January 1996 (Müller et al., 1997a), i.e. over a time period when no substantial chemical ozone loss is expected due to the lack of sunlight. Although significant ozone loss rates (in ppb per hour of sunlight) have been observed for January 1996, the accumulated ozone loss then is still small (Rex et al., 1997). Furthermore, the relationship of the inert compounds $\mathrm{HF}$ and $\mathrm{CH}_{4}$ in the Arctic vortex in 1995-96 is conserved between November 1995 and April 1996 (Fig. 6). Any deviation from the initial $\mathrm{O}_{3} / \mathrm{CH}_{4}$ relation in the vortex over winter and spring is therefore an indication of chemical ozone change.

From this analysis, Müller et al. (1997a) concluded that local chemical $\mathrm{O}_{3}$ destruction has led to reductions of about $60 \%$ over the height range of $400-480 \mathrm{~K}$ (with

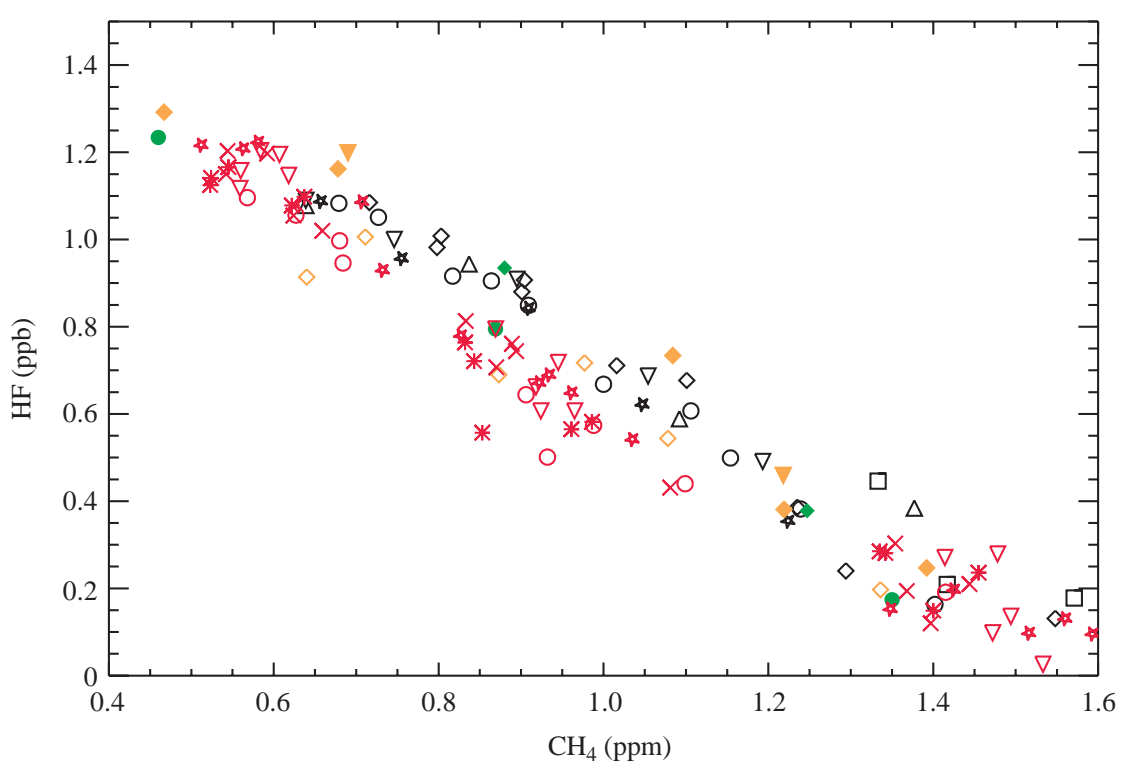

Fig. 6. The relation between $\mathrm{CH}_{4}$ and $\mathrm{HF}$ volume mixing ratios in the Arctic vortex over the winter 1995-96. Black symbols indicate measurements in November 1995, orange symbols in January 1996, green symbols in February 1996, and red symbols in April (1-5) 1996. The conservation is valid for methane mixing ratios of $0.4-1.6 \mathrm{ppmv}$, corresponding to a potential temperature range (in March and April) of 350-600 K. (The symbols indicate individual days: $\square$ 14-Nov-95; $\triangle 15$ Nov-95; $\diamond 20-N o v-95 ; \circ 21-N o v-95 ; \nabla$ 22Nov-95; ᄎ 23-Nov-95; $\nabla 29-J a n-96 ; 30-J a n-96 ;$ $\diamond$ 31-Jan-96; 1-Feb-96; • 28-Feb-96; ○ 1-Apr96; * 2-Apr-96; × 3-Apr-96; 4-Apr-96; * 5Apr-96) 
Table 1. HALOE observations inside the polar vortex in March and April 1996. In the table location, potential vorticity (in potential vorticity units, at $550 \mathrm{~K}$ potential temperature), calculated ozone loss (for the altitude range 350-550 K; 150-25 $\mathrm{hPa}$ ) and the measured ozone column (above $100 \mathrm{hPa}$ ) (both in Dobson units (DU)) of all HALOE observations in the vortex in March and April 1996 is listed. (The date is given as uarsday, e.g. uarsday 1635 is March 3, 1996 and uarsday 1664 is April 1, 1996)

\begin{tabular}{|c|c|c|c|c|}
\hline Uarsday & Latitude & Longitude & Ozone loss & $\begin{array}{l}\text { Observed } \\
\text { column }\end{array}$ \\
\hline 1635. & 51.9 & 24.3 & 135.5 & 196.6 \\
\hline 1636. & 53.7 & 23.4 & 126.2 & 183.5 \\
\hline 1641. & 60.5 & 281.3 & 131.7 & 184.7 \\
\hline 1642. & 61.4 & 280.0 & 139.6 & 183.8 \\
\hline 1642. & 61.4 & 304.1 & 126.5 & 214.2 \\
\hline 1643. & 62.2 & 278.5 & 172.2 & 170.9 \\
\hline 1643. & 62.1 & 302.6 & 167.4 & 189.2 \\
\hline 1644. & 62.8 & 277.0 & 159.8 & 173.7 \\
\hline 1644. & 62.7 & 301.1 & 182.2 & 183.6 \\
\hline 1645. & 63.3 & 275.4 & 161.4 & 184.4 \\
\hline 1645. & 63.2 & 299.5 & 163.5 & 182.2 \\
\hline 1645. & 63.2 & 323.6 & 182.2 & 189.5 \\
\hline 1646. & 63.5 & 273.7 & 158.2 & 185.6 \\
\hline 1646. & 63.5 & 297.8 & 163.9 & 185.4 \\
\hline 1646. & 63.5 & 321.9 & 188.8 & 191.5 \\
\hline 1647. & 63.6 & 272.0 & 166.6 & 177.2 \\
\hline 1647. & 63.6 & 296.1 & 153.9 & 181.7 \\
\hline 1647. & 63.6 & 320.2 & 172.9 & 187.1 \\
\hline 1647. & 63.6 & 344.3 & 157.4 & 216.3 \\
\hline 1648. & 63.5 & 294.3 & 171.6 & 182.1 \\
\hline 1649. & 63.0 & 292.5 & 152.9 & 190.6 \\
\hline 1658. & 63.5 & 13.6 & 120.9 & 179.9 \\
\hline 1658. & 63.3 & 37.6 & 103.2 & 181.7 \\
\hline 1658. & 63.0 & 61.6 & 106.3 & 192.7 \\
\hline 1659. & 66.9 & 350.2 & 109.6 & 197.0 \\
\hline 1659. & 66.7 & 14.1 & 108.6 & 183.6 \\
\hline 1659. & 66.5 & 38.1 & 111.7 & 187.6 \\
\hline 1659. & 66.4 & 62.1 & 120.8 & 193.6 \\
\hline 1660. & 68.9 & 350.8 & 100.3 & 201.3 \\
\hline 1660. & 68.8 & 14.8 & 109.4 & 188.1 \\
\hline 1660. & 68.7 & 38.7 & 122.6 & 184.3 \\
\hline 1660. & 68.6 & 62.7 & 111.8 & 194.1 \\
\hline 1661. & 70.1 & 351.4 & 124.4 & 197.4 \\
\hline 1661. & 70.0 & 15.4 & 137.2 & 186.9 \\
\hline 1661. & 70.0 & 39.4 & 139.0 & 188.0 \\
\hline 1661. & 69.9 & 63.3 & 121.2 & 198.5 \\
\hline 1662. & 70.7 & 351.9 & 123.1 & 195.4 \\
\hline 1662. & 70.6 & 15.9 & 124.2 & 188.3 \\
\hline 1662. & 70.6 & 39.8 & 136.4 & 193.2 \\
\hline 1662. & 70.6 & 63.8 & 113.6 & 206.1 \\
\hline 1663. & 70.8 & 352.1 & 138.8 & 191.3 \\
\hline 1663. & 70.8 & 16.1 & 123.8 & 190.4 \\
\hline 1663. & 70.8 & 40.1 & 124.8 & 196.5 \\
\hline 1663. & 70.8 & 64.1 & 117.8 & 207.2 \\
\hline 1664. & 70.5 & 352.0 & 136.7 & 192.5 \\
\hline 1664. & 70.5 & 16.1 & 133.4 & 191.3 \\
\hline 1664. & 70.6 & 40.1 & 114.1 & 193.9 \\
\hline 1664. & 70.6 & 64.1 & 125.5 & 197.3 \\
\hline 1665. & 70.0 & 351.7 & 135.6 & 196.2 \\
\hline 1665. & 70.0 & 15.8 & 134.8 & 192.6 \\
\hline 1665. & 70.1 & 39.8 & 143.3 & 193.5 \\
\hline 1665. & 70.1 & 63.8 & 128.7 & 192.3 \\
\hline 1666. & 69.2 & 351.2 & 139.8 & 194.1 \\
\hline 1666. & 69.3 & 15.3 & 143.8 & 191.0 \\
\hline 1666. & 69.3 & 39.3 & 133.8 & 192.8 \\
\hline 1666. & 69.4 & 63.3 & 122.9 & 194.2 \\
\hline 1666. & 69.4 & 87.4 & 134.6 & 200.4 \\
\hline 1667. & 68.2 & 350.5 & 123.5 & 206.1 \\
\hline 1667. & 68.3 & 14.5 & 120.9 & 191.6 \\
\hline
\end{tabular}

Table 1. (Continued)

\begin{tabular}{llrll}
\hline Uarsday & Latitude & Longitude & Ozone loss & $\begin{array}{l}\text { Observed } \\
\text { column }\end{array}$ \\
\hline 1667. & 68.4 & 38.6 & 133.9 & 189.0 \\
1667. & 68.4 & 62.6 & 136.4 & 193.1 \\
1667. & 68.5 & 86.7 & 129.5 & 203.2 \\
1668. & 67.0 & 349.6 & 135.9 & 199.3 \\
1668. & 67.1 & 13.6 & 113.0 & 195.8 \\
1668. & 67.2 & 37.7 & 133.9 & 190.5 \\
1668. & 67.3 & 61.8 & 119.9 & 194.3 \\
1668. & 67.4 & 85.8 & 116.2 & 206.3 \\
1669. & 65.8 & 12.6 & 119.8 & 185.0 \\
1669. & 65.9 & 36.7 & 123.4 & 199.3 \\
1669. & 65.9 & 60.7 & 112.5 & 203.1 \\
1669. & 66.0 & 84.8 & 123.4 & 198.1 \\
1670. & 64.3 & 35.5 & 130.3 & 197.0 \\
1670. & 64.4 & 59.6 & 136.1 & 214.5 \\
1670. & 64.6 & 83.6 & 128.1 & 212.4 \\
1671. & 62.7 & 34.2 & 134.9 & 197.7 \\
1671. & 62.8 & 58.3 & 144.1 & 229.3 \\
1671. & 62.9 & 82.4 & 146.9 & 237.4 \\
1671. & 63.0 & 106.4 & 125.2 & 230.3 \\
1672. & 60.8 & 32.8 & 125.5 & 197.2 \\
1672. & 60.9 & 56.9 & 140.6 & 233.2 \\
1673. & 58.8 & 31.3 & 133.8 & 198.6 \\
1673. & 58.9 & 55.4 & 140.8 & 235.0 \\
\hline & & & &
\end{tabular}

peak losses of about $70 \%$ ) between late January and early April. This is consistent with the results of Rex et al. (1997), who infer an ozone loss rate of 27-34 ppb per day in the lower stratosphere over this period from ozonesonde measurements that corresponds to an accumulated $\mathrm{O}_{3}$ loss at about $470 \mathrm{~K}$ of $\approx 64 \%$. Somewhat lower ozone loss rates $(22 \mathrm{ppb}$ per day for February 1996) are derived from MLS observations (Manney et al., 1996b), the temporal behaviour of $\mathrm{O}_{3}$, however is very similar.

The local chemical ozone loss in the vortex in the lower stratosphere that is reflected in a change in the relation of $\mathrm{O}_{3}$ and $\mathrm{CH}_{4}$ mixing ratios over winter and early spring, may be integrated to calculate the chemical change in column ozone: We use the "early vortex" $\mathrm{O}_{3} /$ $\mathrm{CH}_{4}$ relationship (Table 3) to compute a proxy for the "unperturbed" ozone $\left(\mathrm{O}_{3}\right)$, expected for March and April in the absence of chemical change. The separation between the observed and the proxy ozone profiles is a measure of the accumulated chemical ozone loss over winter and early spring (Müller et al., 1996, 1997a). Therefore, vertically integrating over the difference between measured and proxy ozone, yields a diagnostic measure of the deficit in column ozone in March/April in the lower stratosphere (between about 150 and $25 \mathrm{hPa}$ ). Note that this calculation is not affected by complications of the seasonal change in total ozone (see earlier) as we focus here solely on the situation in March/April and use $\mathrm{CH}_{4}$ as a reference frame, thereby taking the effect of diabatic descent in the polar winter latitudes into account. In Table 1, the ozone column loss for each individual HALOE profile in the vortex during March and April 1996 is listed. All vortex measurements show severe chemical ozone loss exceeding 100 DU, where typical values range between 120-160 DU. In Table 1 
also noted are the column ozone (above $100 \mathrm{hPa}$ ) observed by HALOE as a reference and the PV at the $550 \mathrm{~K}$ isentropic level (calculated from UKMO meteorological analyses) as an approximate indication of the location of the observation relative to the vortex boundary. Moreover, column ozone and the PV at $550 \mathrm{~K}$ is listed in Table 2 for the HALOE vortex observations in November 1995 and in January 1996 for completeness.

\section{GOME observations}

The Global Ozone Monitoring Experiment (GOME) is a new passive remote sensing instrument launched by ESA aboard the second European Research Satellite (ERS-2) on 21. April 1995 (Burrows et al., 1993, and references therein). The total column amount is retrieved from GOME measurements in the wavelength range between 325 and $335 \mathrm{~nm}$ of the upwelling radiance from the atmosphere and the extra-terrestrial irradiance. The technique known as differential optical absorption

Table 2. Location and potential vorticity (in potential vorticity units, at $550 \mathrm{~K}$ potential temperature) of HALOE observations inside the vortex in November 1995 and January 1996. The measured ozone column above $100 \mathrm{hPa}$ (in DU) is listed as well. (The date is given as uarsday e.g. uarsday 1525 is November 14, 1995 and uarsday 1601 is January 29, 1996). For January 1996 MLS measurements for the column ozone above $100 \mathrm{hPa}$ are available for comparison. The mean MLS ozone column (Version 4) close to the HALOE measurement locations (within $10^{\circ}$ latitude and $20^{\circ}$ longitude) is $314 \mathrm{DU}, 307 \mathrm{DU}$, and $299 \mathrm{DU}$ for uarsdays 1601,1602 , and 1603 respectively (G. Manney, personal communication, 1998)

\begin{tabular}{llrll}
\hline Uarsday & Latitude & Longitude & $\begin{array}{l}\text { Potential } \\
\text { vorticity }\end{array}$ & $\begin{array}{l}\text { Observed } \\
\mathrm{O}_{3} \text { column }\end{array}$ \\
\hline 1525 & 50.9 & 27.7 & 52.9 & 270.4 \\
1526 & 51.0 & 338.2 & 50.8 & 202.8 \\
1529 & 50.3 & 359.2 & 66.0 & 260.0 \\
1531 & 49.3 & 94.2 & 55.7 & 244.6 \\
1531 & 49.1 & 22.1 & 60.5 & 242.2 \\
1532 & 48.4 & 117.8 & 60.7 & 268.5 \\
1532 & 48.2 & 21.7 & 59.5 & 243.1 \\
1533 & 47.3 & 117.6 & 67.1 & 265.2 \\
1534 & 46.0 & 117.6 & 65.9 & 252.7 \\
1601 & 50.1 & 267.3 & 67.7 & 325.1 \\
1602 & 49.3 & 267.4 & 53.9 & 292.4 \\
1603 & 48.2 & 267.7 & 59.8 & 256.3 \\
\hline
\end{tabular}

spectroscopy (DOAS) is used (Eisinger et al., 1997, and references therein).

GOME measurements of total ozone in high northern latitudes in late winter and early spring 1996 show very low values in March 1996 (Fig. 7) in accordance with total ozone derived from SBUV-2 (Newman et al.,

\section{ERS-2 GOME Monthly Mean: March 1996}
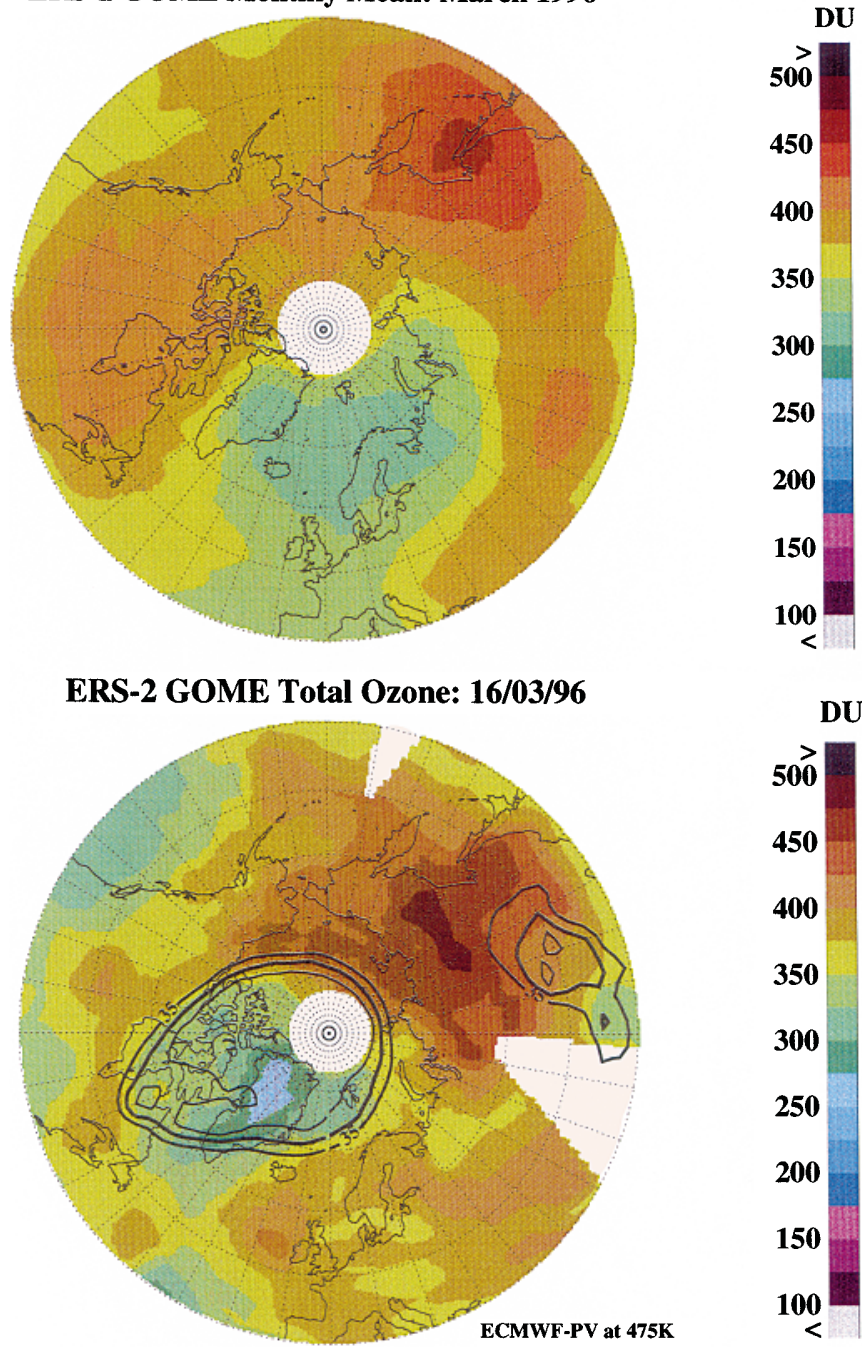

Fig. 7. GOME total ozone measurements in March 1996. Top panel: monthly mean total ozone in the Northern Hemisphere for March 1996. Bottom panel: total ozone on 16 March 1996. Black lines indicate the edge of the vortex; contour lines for 35 (thick line with label), 42 (thick line) and 48 (thin line) $10^{-6} \mathrm{~K} \mathrm{~m}^{2}\left(\mathrm{~kg} \mathrm{~s}^{-1}\right.$ are shown

Table 3. The early vortex $\mathrm{CH}_{4} / \mathrm{O}_{3}$ relation

\begin{tabular}{ll}
\hline Year & $\mathrm{CH} 4 / \mathrm{O}_{3}$ relationship \\
\hline 1991 & $\mathrm{O}_{3}=19.52 \cdot \mathrm{CH}_{4}^{4}-81.63 \cdot \mathrm{CH}_{4}^{3}+119.84 \cdot \mathrm{CH}_{4}^{2}-75.43 \cdot \mathrm{CH}_{4}+21.38$ \\
1992 & $\mathrm{O}_{3}=5.69 \cdot \mathrm{CH}_{4}^{3}-19.25 \cdot \mathrm{CH}_{4}^{2}+15.96 \cdot \mathrm{CH}_{4}+0.75$ \\
1993 & $\mathrm{O}_{3}=6.47 \cdot \mathrm{CH}_{4}^{3}-22.17 \cdot \mathrm{CH}_{4}^{2}+19.40 \cdot \mathrm{CH}_{4}-0.33$ \\
1994 & $\mathrm{O}_{3}=5.08 \cdot \mathrm{CH}_{4}^{3}-17.31 \cdot \mathrm{CH}_{4}^{2}+14.61 \cdot \mathrm{CH}_{4}+0.60$ \\
1995 & $\mathrm{O}_{3}=2.98 \cdot \mathrm{CH}_{4}^{3}-11.20 \cdot \mathrm{CH}_{4}^{2}+9.52 \cdot \mathrm{CH}_{4}+2.14$ \\
\hline
\end{tabular}

The empirical $\mathrm{CH}_{4} / \mathrm{O}_{3}$ relation (for $\mathrm{O}_{3}$ and $\mathrm{CH}_{4}$ in ppmv) from early vortex measurements for the five winters considered (based on version 18 HALOE data). The relations for 1991 and 1992 are valid for $\mathrm{CH}_{4}=0.5-1.5$ ppmv, those for 1993 and 1994 for $\mathrm{CH}_{4}=0.6-1.5 \mathrm{ppmv}$, and the one for 1995 for $\mathrm{CH}_{4}=0.5-$ 1.6 ppmv. (Updated version of Table 5 of Müller et al., 1996) 
1997). Throughout this region, monthly mean total ozone values between 300-475 DU are observed for March 1996, while the corresponding March monthly mean values between 1971 and 1980 range from 360-520 DU (Newman et al., 1997). Typical long-term climatological values for March total ozone from the Dobson station Tromsø $\left(69.4^{\circ} \mathrm{N}\right)$ are $\approx 440 \pm 50$ DU (Hansen et al., 1997) and the March average over the polar region (from $63^{\circ} \mathrm{N}$ to $90^{\circ} \mathrm{N}$ ) from BUV and Nimbus 7 TOMS total ozone measurements during the eighties (1971-80), is about $470 \mathrm{DU}$ (Newman et al., 1997).

The low ozone regions in Fig. 7 are related to the location of the polar vortex, which was generally centred off the pole towards northern Europe (Naujokat and Pawson, 1996; Manney et al., 1996b) in early 1996. Indeed, the region of low total ozone in early 1996 is in general colocated with the position of the polar vortex. In Fig. 7 the ozone distribution on March 16, 1996 (see also Fig. 4) is shown; defining the edge of the vortex at $\approx$ 35 PVU (Rummukainen et al., 1994; Rex et al., 1997), which corresponds to the maximum gradient in potential vorticity, clearly, the low total ozone values occur within the confines of the polar vortex. This finding is consistent with MLS observations which show that the region of very low ozone mixing ratios in the lower stratosphere (at $\approx 465 \mathrm{~K}$ ) in early 1996 is situated inside the polar vortex (Manney et al., 1996b) and with HALOE measurements of the ozone vertical profile that show very low mixing ratios inside the polar vortex in March and early April 1996 (Müller et al., 1997a). These observations are in accordance with the notion that substantial chemical ozone loss occurred inside the vortex in early 1996.

\section{Discussion of uncertainties in the analysis of the HALOE observations}

The $\mathrm{O}_{3} / \mathrm{CH}_{4}$ relation in the incipient vortex in 1995

The reliability of a method employing ozone-tracer relationships to deduce chemical ozone loss, depends on

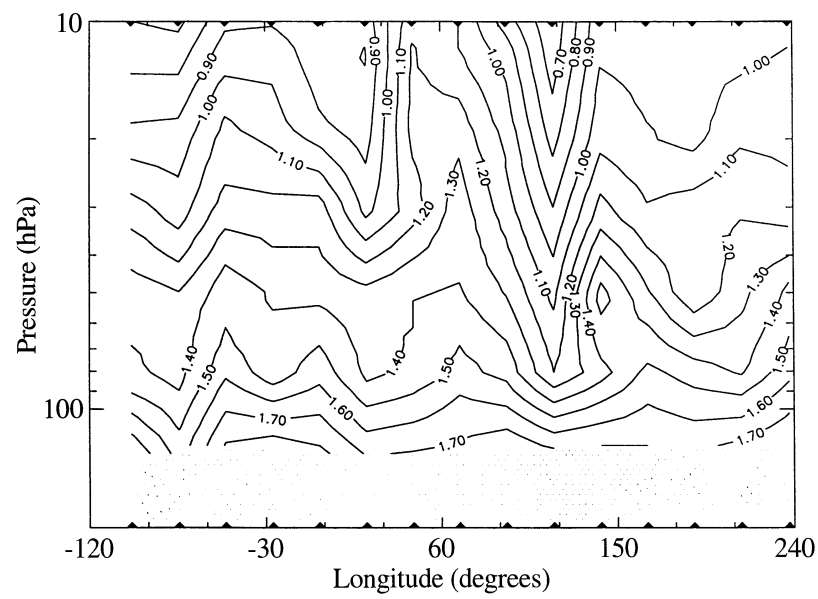

Fig. 8. Observations by HALOE at sunset on November 22, 1995 at $47^{\circ} \mathrm{N}$. $\mathrm{CH}_{4}$ mixing ratios (in ppmv) are shown against pressure and longitude. The black triangles indicate the longitude of the HALOE measurements

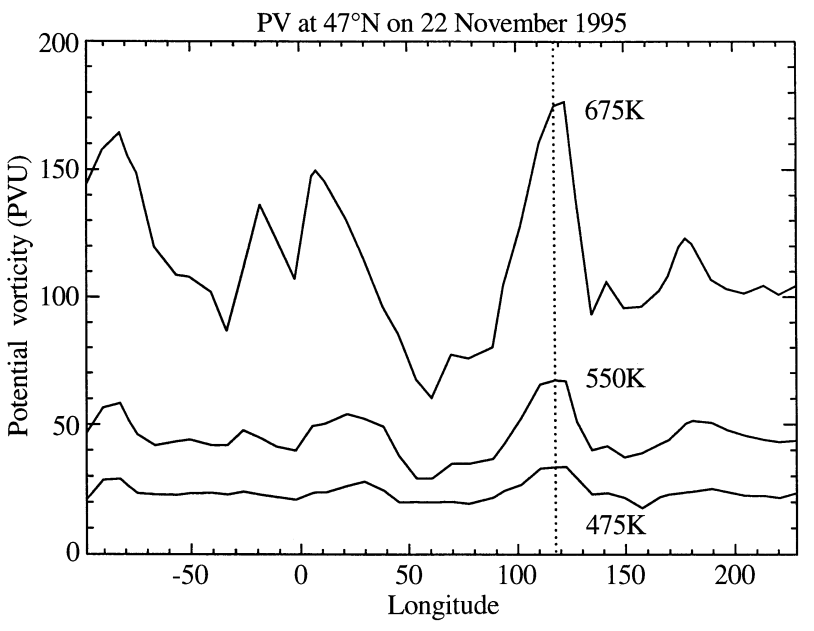

Fig. 9. Potential vorticity on November 22,1995 at $47^{\circ} \mathrm{N}$ at three potential temperature surfaces against longitude. Dotted line indicates the location of the HALOE observation inside the vortex. Potential vorticity is derived from UK-Meteorological Office (UKMO) meteorological analyses

the quality of the initial ozone-tracer relation, which is used as a reference state for the conditions before the onset of chemical ozone destruction. Müller et al. (1997a) have used an empirical $\mathrm{O}_{3}$ versus $\mathrm{CH}_{4}$ relation

$\mathrm{O}_{3}=2.98\left(\mathrm{CH}_{4}\right)^{3}-11.20\left(\mathrm{CH}_{4}\right)^{2}+9.52\left(\mathrm{CH}_{4}\right)+2.14$

(for $\mathrm{O}_{3}$ and $\mathrm{CH}_{4}$ in ppmv and valid for $0.5 \mathrm{ppmv}<\mathrm{CH}_{4}$ $<1.6 \mathrm{ppmv}$ ), derived from HALOE vortex observations in late November 1995 as a reference. One needs to demonstrate that this relation in the vortex, shortly after its formation phase in early November (Coy et al., 1997), is accurately known and is not influenced substantially by out of vortex air. The joint occurrence of low methane mixing ratios, indicating diabatic descent, and high PV, both characteristics of vortex air, is used as a criterion to discriminate vortex from out

Table 4. Location and potential vorticity (in potential vorticity units, at $550 \mathrm{~K}$ potential temperature) of HALOE observations at $47^{\circ} \mathrm{N}$ on November 22, 1995 (uarsday 1533)

\begin{tabular}{lll}
\hline Latitude & Longitude & Potential vorticity \\
\hline 46.6 & -98.4 & 46.1 \\
46.7 & -74.4 & 46.0 \\
46.8 & -50.5 & 44.1 \\
46.8 & -26.4 & 47.7 \\
46.9 & -2.4 & 39.9 \\
47.0 & 21.6 & 54.0 \\
47.1 & 45.6 & 37.9 \\
47.2 & 69.6 & 34.8 \\
47.3 & 93.6 & 42.2 \\
47.3 & 117.6 & 67.1 \\
47.4 & 141.6 & 41.6 \\
47.5 & 165.6 & 42.3 \\
47.6 & 189.6 & 50.6 \\
47.7 & 213.6 & 44.0 \\
47.7 & 237.6 & 41.0 \\
\hline
\end{tabular}


of vortex observations. However, in Müller et al. (1996), where this issue has been discussed in some detail, only examples of an application of the methodology for the winters 1991-92 and 1992-93 are shown. Therefore, we present here a typical example of a HALOE observation inside the "early vortex" in 1995-96, namely on November 22, 1995 (uarsday 1533).

In Fig. 8, the HALOE observations of $\mathrm{CH}_{4}$ mixing ratios on November 22, 1995 at $47^{\circ} \mathrm{N}$ are shown against pressure and longitude. Note that the longitude-height pattern is very similar to a presentation where potential temperature is used as a vertical coordinate (Fig. 2). The air inside the vortex at $118^{\circ} \mathrm{E}$ clearly stands out as a region of low $\mathrm{CH}_{4}$ mixing ratios, which are caused by diabatic descent. Indeed, the potential vorticity at this location is enhanced throughout the lower stratosphere
(Fig. 9; Table 4); an observation which corroborates the classification of this air mass as vortex air.

As observed in earlier winters (Müller et al., 1996), the $\mathrm{O}_{3} / \mathrm{CH}_{4}$ relationship inside the vortex in mid and late November 1995 is clearly distinct from that observed outside (Fig. 10). Further, the outside vortex relations show much more variability than those inside the vortex and the ozone mixing ratios for a given $\mathrm{CH}_{4}$ mixing ratio are larger outside than inside the vortex (Fig. 10). Moreover, the ozone vertical profiles measured inside the vortex in November 1995 are distinct from the profiles measured outside (Fig. 11); on constant potential temperature $(\Theta)$ surfaces, they generally show higher ozone mixing ratios inside the vortex than outside. This observation is consistent with the notion of an ozone increase on $\Theta$-surfaces caused by the subsi-
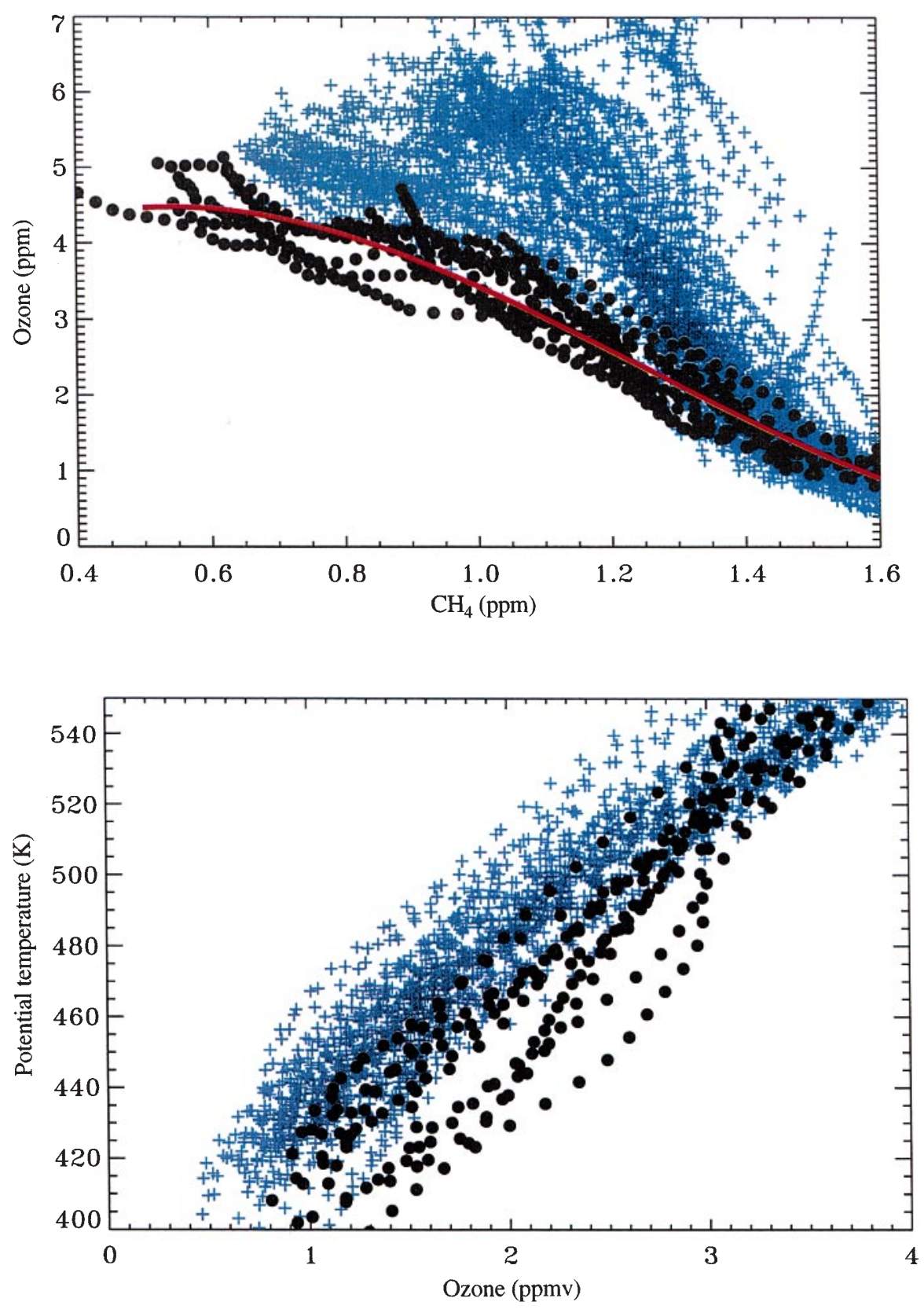

Fig. 10. HALOE measurements of the $\mathrm{O}_{3} /$ $\mathrm{CH}_{4}$ relationship in early November 1995 . The complete set of sunset data for all November observations listed in Table 2 is shown. Measurements inside the vortex are shown as black circles, outside measurements are shown as blue plus signs. Overplotted in red is the early vortex relation (Eq. 1)

Fig. 11. As Fig. 10, but showing vertical profiles of $\mathrm{O}_{3}$ mixing ratio (in ppmv) against potential temperature as the vertical coordinate. Measurements inside the vortex are shown as black circles, outside measurements are shown as blue plus signs 
dence of air inside the vortex (as long as air is transported downwards from below the ozone mixing ratio maximum). Thus, the "early vortex" $\mathrm{CH}_{4} / \mathrm{O}_{3}$ relation (Eq. 1) may be considered as characteristic of the incipient vortex.

Differences in the ozone losses deduced from HALOE data versions 17 and 18

An examination of the $\mathrm{O}_{3} / \mathrm{CH}_{4}$ relationships between November/December and March/April for the first five winters of HALOE observations in the Arctic revealed reductions in ozone inside the vortex region, clearly manifested by significantly lower $\mathrm{O}_{3}$ volume mixing ratios for equal values of the $\mathrm{CH}_{4}$ mixing ratio (Müller et al., 1996). This study was based on HALOE version 17 (V17) data. A reanalysis of the derived ozone loss for those winters based on version 18 (V18) data (Müller et al., 1997a) yielded larger calculated ozone losses. The reason for the observed increase in the calculated ozone losses when V18 data are used instead of V17, is due to a combination of several smaller changes in the HALOE data, which sum up to the observed effect. Firstly, $\mathrm{O}_{3}$ mixing ratios have increased from V17 to V18. Therefore, the empirical $\mathrm{O}_{3} / \mathrm{CH}_{4}$ relations derived from V18 data show larger ozone mixing ratios (Table 3). However, the increase is stronger at higher altitudes and for larger $\mathrm{O}_{3}$ mixing ratios, so that the estimated ozone loss increases. (We have also verified this through sensitivity calculations.) Further, $\mathrm{CH}_{4}$ mixing ratios at lower altitudes (below about 50-70 hPa) have decreased from V17 to V18, which also leads to an increase in the calculated ozone loss. Both effects together are responsible for the fact that the ozone loss calculated previously from V17 data was underestimated.

There is a remaining uncertainty in V18 data, however, regarding $\mathrm{CH}_{4}$ measurements at sunrise (SR) at lower altitudes, below $\approx 50 \mathrm{hPa}$, namely that $\mathrm{CH}_{4}$ mixing ratios are possibly underestimated below this
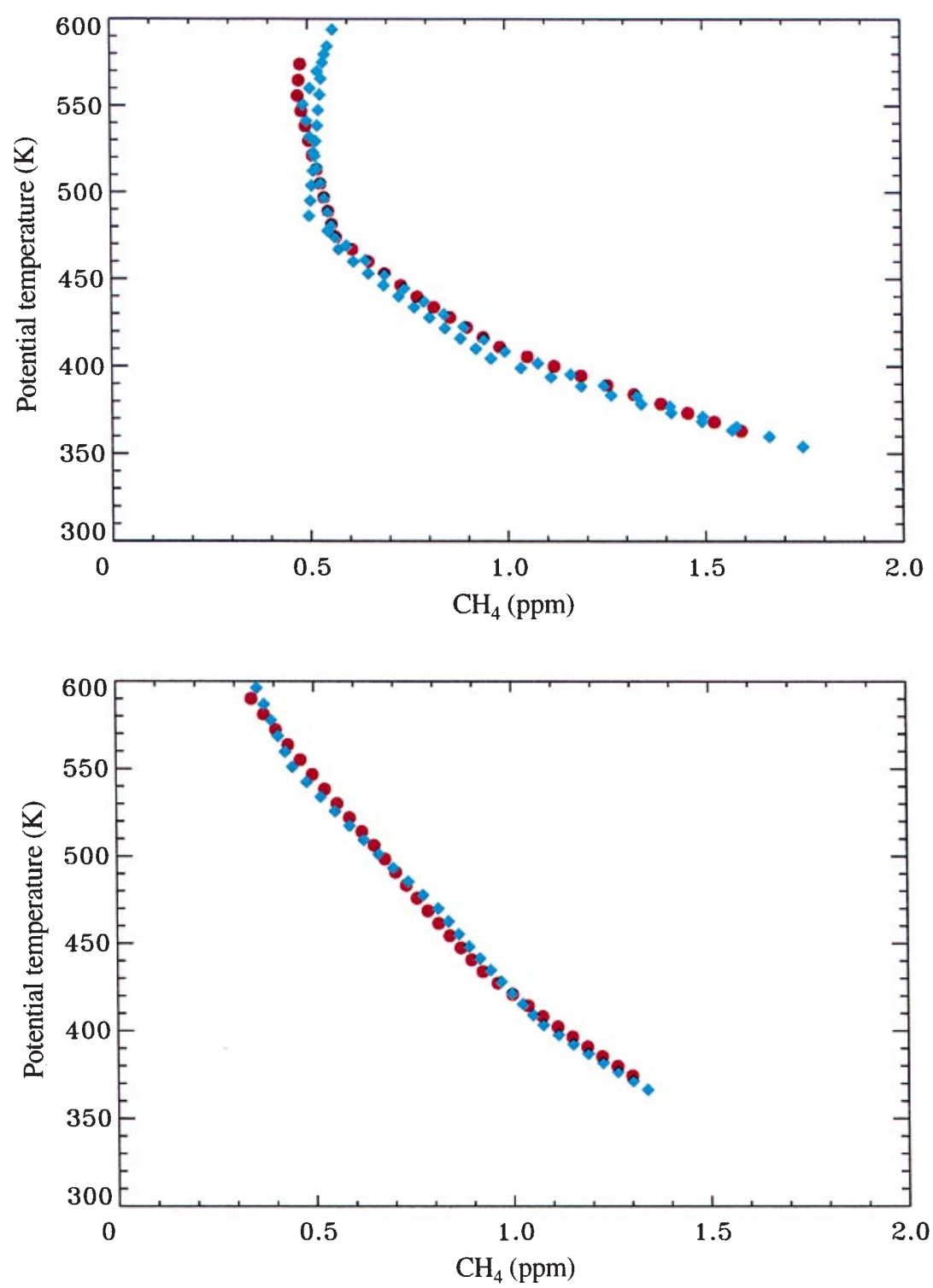

Fig. 12. Comparison of $\mathrm{CH}_{4}$ vertical profiles observed at sunrise and sunset in the Arctic vortex. Top panel: observations on April 7, 1993 (uarsday 574); sunset observations (at $65.4^{\circ} \mathrm{N}$, $11.2^{\circ} \mathrm{E}$ and $62.9^{\circ} \mathrm{N}, 105.8^{\circ} \mathrm{E}$ ) are indicated by the cyan diamonds, sunrise observations (at $59.6^{\circ} \mathrm{N}$, $353.2^{\circ} \mathrm{E}$ ) are indicated by the red circles. Bottom panel: observations on April 2, 1994 (uarsday 934), sunset observations at $56.4^{\circ} \mathrm{N}, 288.9^{\circ} \mathrm{E}$ (cyan diamonds) and sunrise observations at $55.2^{\circ} \mathrm{N}$, $282.6^{\circ} \mathrm{E}$ (red circles) 
altitude by $<10-15 \%$. Since the observations in the incipient vortex in November 1995 (and in all other winters as well), are taken at sunset (SS), this implies a possible overestimate of the calculated loss in the ozone column for SR observations. Sensitivity calculations, performed to derive an estimate of the consequences of this potential problem indicate that $35 \mathrm{DU}$ is an upper limit for the possible overestimate. The SS observations in the vortex in early 1996 (26 March to 15 April), however, are not affected by this uncertainty in V18 data. Moreover, this question is related to an uncertainty in the accuracy of the HALOE sun tracking, a problem which is to a large extent caused by the stratospheric aerosol layer. In the polar vortex, however, the stratospheric aerosol is strongly reduced due to diabatic descent (Browell et al., 1993; Wirth et al., 1994). Indeed, the $\mathrm{O}_{3} / \mathrm{CH}_{4}$ relations inside the vortex derived on two occasions where SS and SR measurements overlap inside the Arctic vortex (Figs. 12, 13) show good agreement. Furthermore, preliminary V19 data available for SS/SR overlap, for which the problem with the HALOE sun tracking is expected to be solved, indicate that the $\mathrm{CH}_{4} / \mathrm{O}_{3}$ relation does not change substantially between V18 and V19 for SR vortex observations.

\section{Comparison of HALOE measurements with other observations in the winter 1995-96}

Although for the winter 1995-96 no other direct measurements of the $\mathrm{CH}_{4} / \mathrm{O}_{3}$ relation are available, the comparison of the HALOE derived $\mathrm{CH}_{4} / \mathrm{O}_{3}$ relation for the early winter 1991, where such measurements are available, showed good agreement (Müller et al., 1996). Moreover, the comparison of HALOE ozone profiles within the Arctic vortex in 1995-96 with observations by
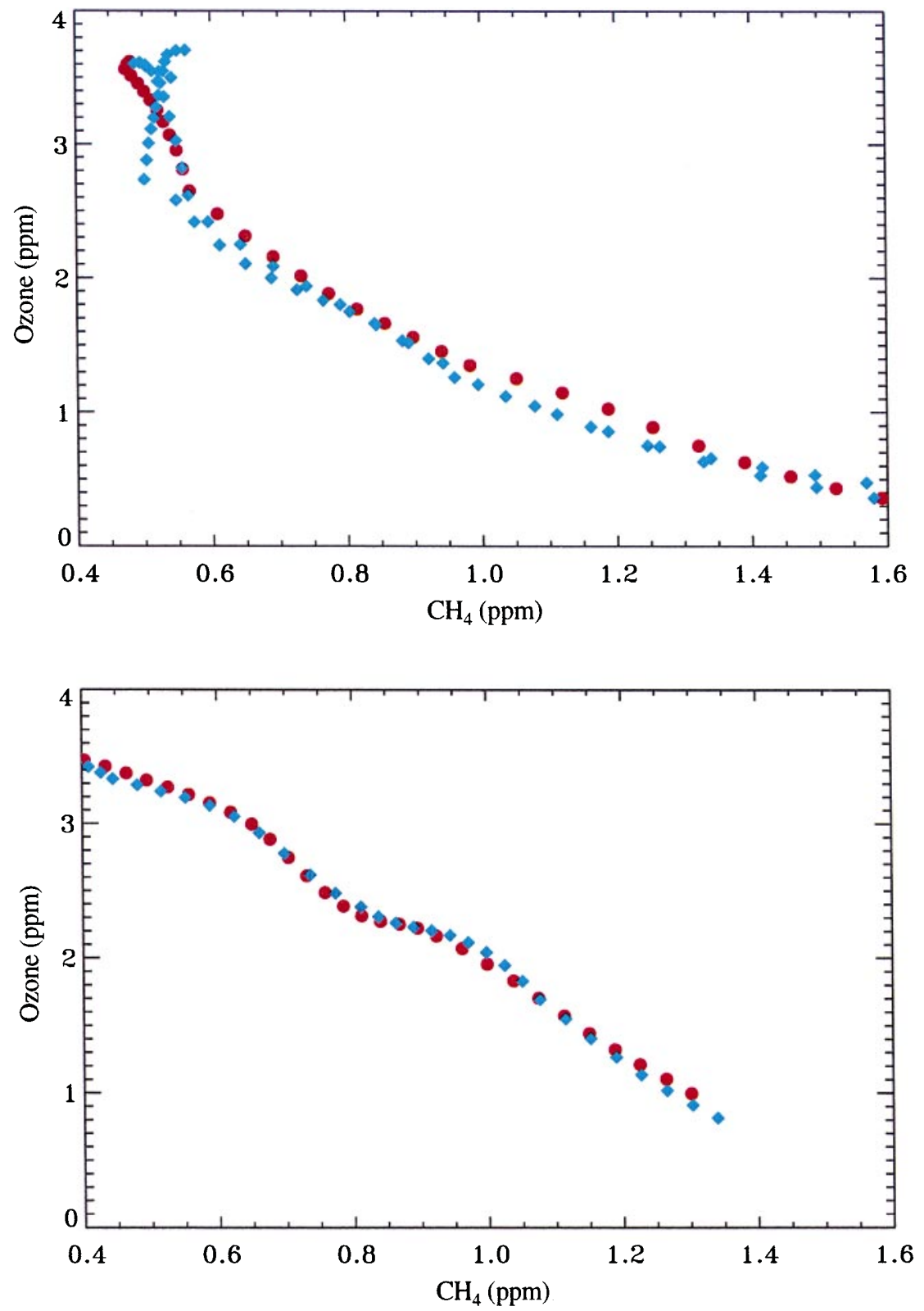

Fig. 13. As Fig. 12, but showing the relation of $\mathrm{CH}_{4}$ versus $\mathrm{O}_{3}$ 
the Microwave Limb Sounder (MLS) aboard UARS on March 3, 1996 (Fig. 14) and ground-based lidar observations (Donovan et al., 1996) (Figs. 15, 16) both in March 1996 and November and December 1995 shows good agreement. Both this agreement as well as the relative homogeneity of the HALOE (Müller et al., 1997a) and of the lidar ozone profiles (Donovan et al., 1996) inside the vortex in March and April 1996, if potential temperature is used as the vertical coordinate, indicate that the ozone mixing ratios inside the Arctic polar vortex are fairly homogeneous at this time. The variation among individual ozone profiles observed by HALOE throughout the lower stratosphere in March and early April 1996 is typically $\approx 0.5 \mathrm{ppm}$. The clearly stronger variability seen in the total ozone observations (see also Fig. 7) are strongly correlated with lower stratospheric temperatures (Manney et al., 1996b, Fig. 8). This is typically the case for short-term fluctuations in total ozone, which are caused dynamically by tropospheric disturbances (e.g. Dobson et al., 1929; McKenna et al., 1989).

A further important quantity which has an impact on the conclusions regarding chemical ozone loss, is the descent rate implied by the HALOE $\mathrm{CH}_{4}$ observations. Unfortunately, to our knowledge, there are no studies of the descent rates in the Arctic vortex for the winter 1995-96. There are problems in comparing descent rates derived for different Arctic winters, which show a certain year to year variability (Müller et al., 1996) and, even more, descent rates for different hemispheres (Manney et al., 1994b; Rosenfield et al., 1994; Lahoz et al., 1996). Further, estimates of the descent rate in the vortex from the motion of tracer isopleths across

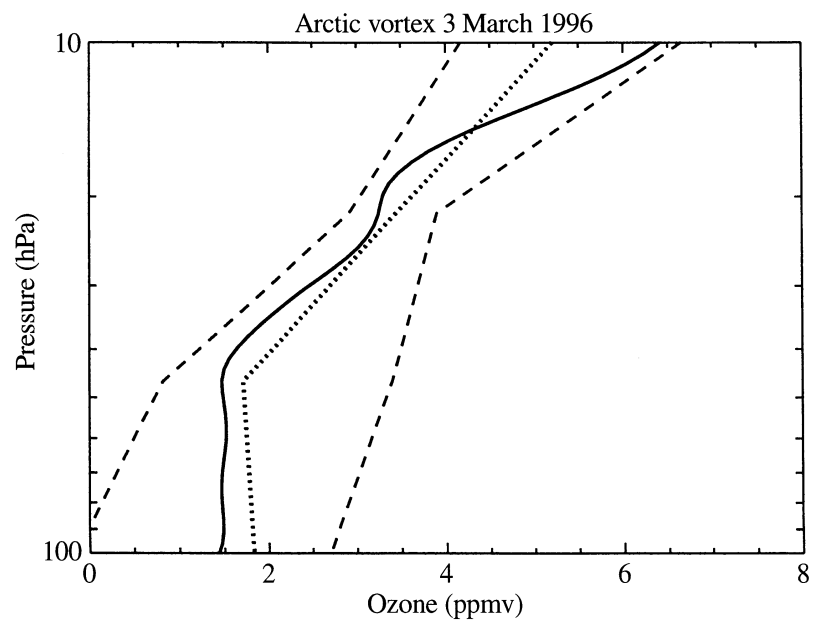

Fig. 14. The ozone profile observed by HALOE on March 3, 1996 at $51.9^{\circ} \mathrm{N}$ and $24.3^{\circ} \mathrm{E}$ inside the vortex (solid line) compared with 14 MLS (Version 4) profiles (G.Manney, personal communication 1997). The MLS data were selected to fulfil the following requirements: (1) latitude between $45^{\circ}$ and $60^{\circ} \mathrm{N}$ : (2) longitude between $340^{\circ}$ and $360^{\circ}$ or $0^{\circ}$ and $60^{\circ} \mathrm{E}$ : (3) UKMO PV at $465 \mathrm{~K}$ greater than $2.510^{-5} \mathrm{~K} \mathrm{~m}^{2}$ $(\mathrm{kg} \mathrm{s})^{-1}$, so that they are comparable with the HALOE measurements. The two dashed lines show the range of the MLS observations, their mean value is indicated by the dotted line. The comparable values for the column ozone above $100 \mathrm{hPa}$ are $197 \mathrm{DU}$ and $195 \mathrm{DU}$ for HALOE and MLS respectively

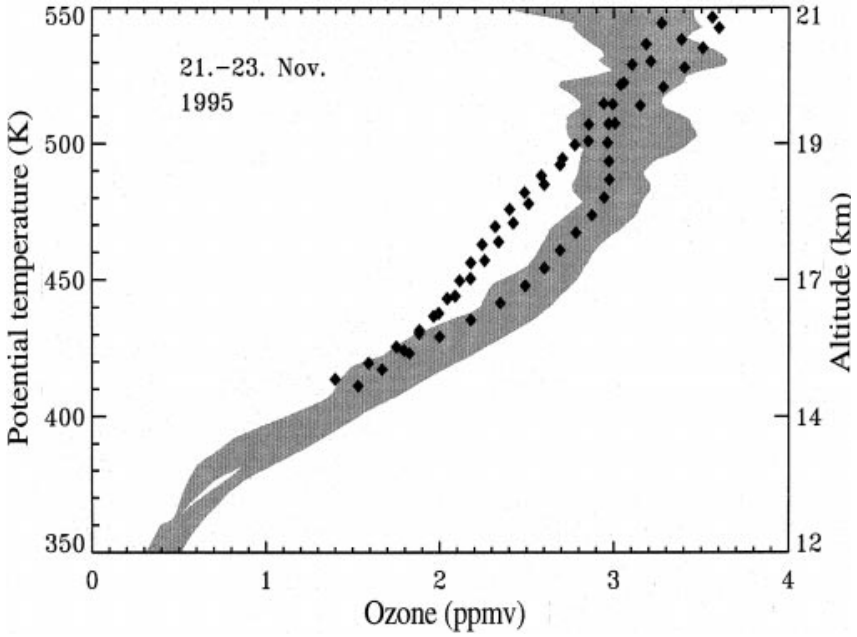

Fig. 15. The ozone profiles observed by HALOE in late November 1995 inside the vortex (diamonds) compared with ground-based lidar observations (at $80.0^{\circ} \mathrm{N}, 86.4^{\circ} \mathrm{W}$ ) inside the vortex (Donovan et al., 1996) between November 29, and December 29, 1995. The grey area indicates the variation of the lidar profiles by \pm one standard deviation around the mean profile

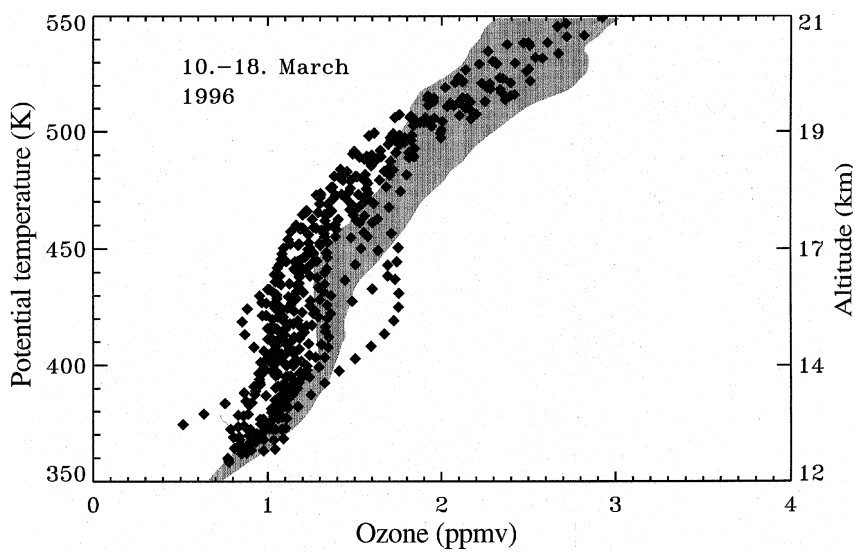

Fig. 16. As Fig. 15, but HALOE ozone profiles in March 1996 in the vortex (diamonds) compared with lidar observations (Donovan et al., 1996) between March 10 and March 22, 1996

isentropes constitute only a lower limit of the actual descent rate (Tuck and Proffitt, 1998). Figure 17 shows the methane vertical profiles measured by HALOE on April 7, 1993 at $64^{\circ} \mathrm{N}$, which may be directly compared to Fig. 3 of Abrams et al. (1996) and which show very good agreement. Consequently, the implied lower limit of the descent rates $(\approx 0.8 \mathrm{~km} /$ month at $20 \mathrm{~km})$ are in accordance as well. Further, we show in Fig. 18 that the morphology of the $\mathrm{CH}_{4}$ vertical profiles in the high latitudes in early April 1996 is not too distinct from what is observed by both ATMOS (Abrams et al., 1996) and HALOE (Fig. 17) in 1993.

Moreover, HALOE $\mathrm{HCl}$ observations provide information on the extent of chlorine activation. Extremely low $\mathrm{HCl}$ mixing ratios were observed in early March 1996 (Müller et al., 1997a), demonstrating the occurrence of chlorine activation in late winter 1996. This finding is consistent with the observation of a 


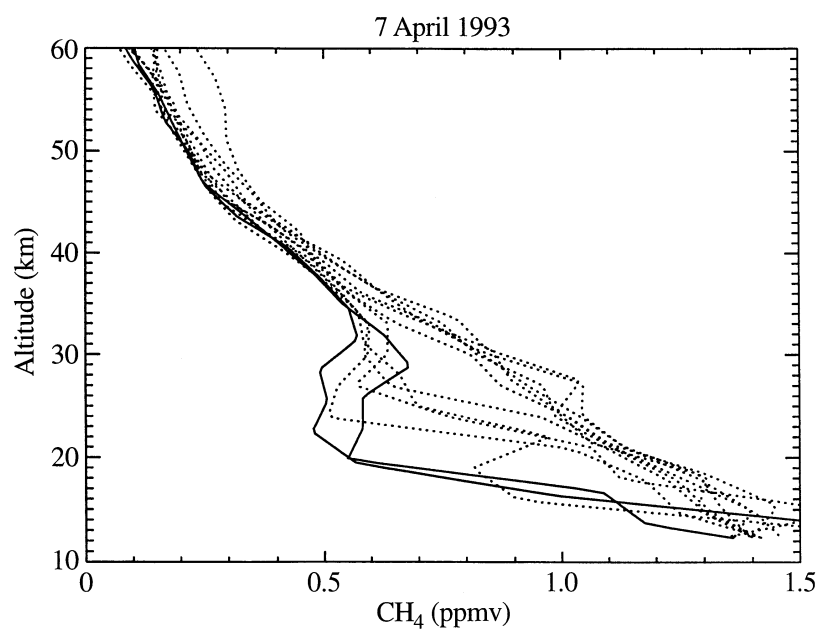

Fig. 17. HALOE measurements of $\mathrm{CH}_{4}$ vertical profiles at $60^{\circ} \mathrm{N}$ on April 7, 1993. Measurements clearly inside the polar vortex are shown as solid lines, those outside and at the vortex edge by dotted lines

large scale, severe decrease in gas-phase $\mathrm{HNO}_{3}$ by MLS (Santee et al., 1996a) and the simultaneous observation of very large aerosol extinction by HALOE (Fig. 19) on March 3, 1996 (in high northern latitudes around $0^{\circ} \mathrm{W}$ ), both indicative of extensive PSC formation. Because the deactivation of chlorine in the Arctic requires more than 2-3 weeks (Müller et al., 1994; Douglass et al., 1995; Santee et al., 1996b) ozone loss must have continued during March 1996; a conclusion which is in accordance with the ozone loss

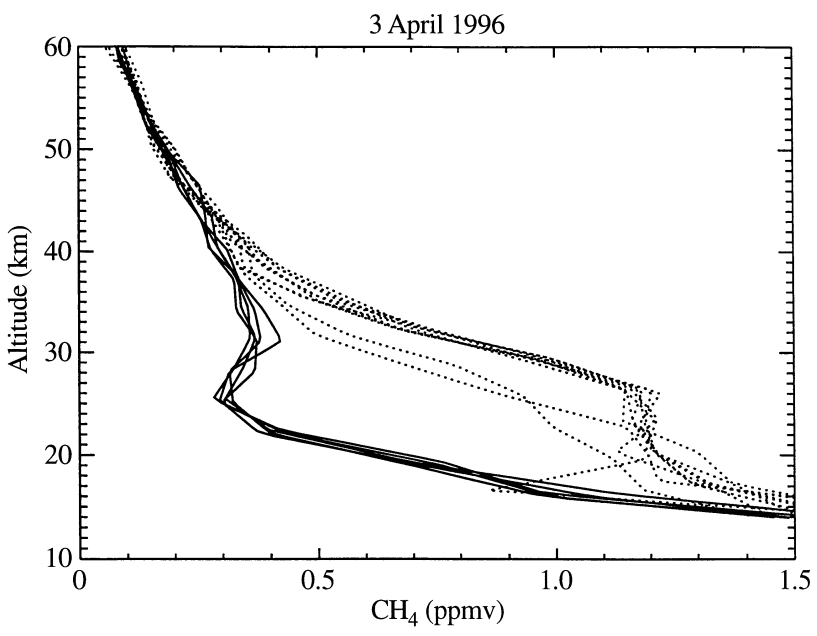

Fig. 18. As Fig. 17, but for HALOE measurements of $\mathrm{CH}_{4}$ vertical profiles at $69^{\circ} \mathrm{N}$ on April 3, 1996

rates deduced from the Match ozonesonde-campaign in 1995-96 (Rex et al., 1997).

\section{Conclusions}

We have examined simultaneous HALOE observations of $\mathrm{O}_{3}$ with a chemically inert tracer $\left(\mathrm{CH}_{4}\right)$, inside the Arctic vortex in the winter and spring of 1995-96 to detect chemical ozone depletion in the lower strato-

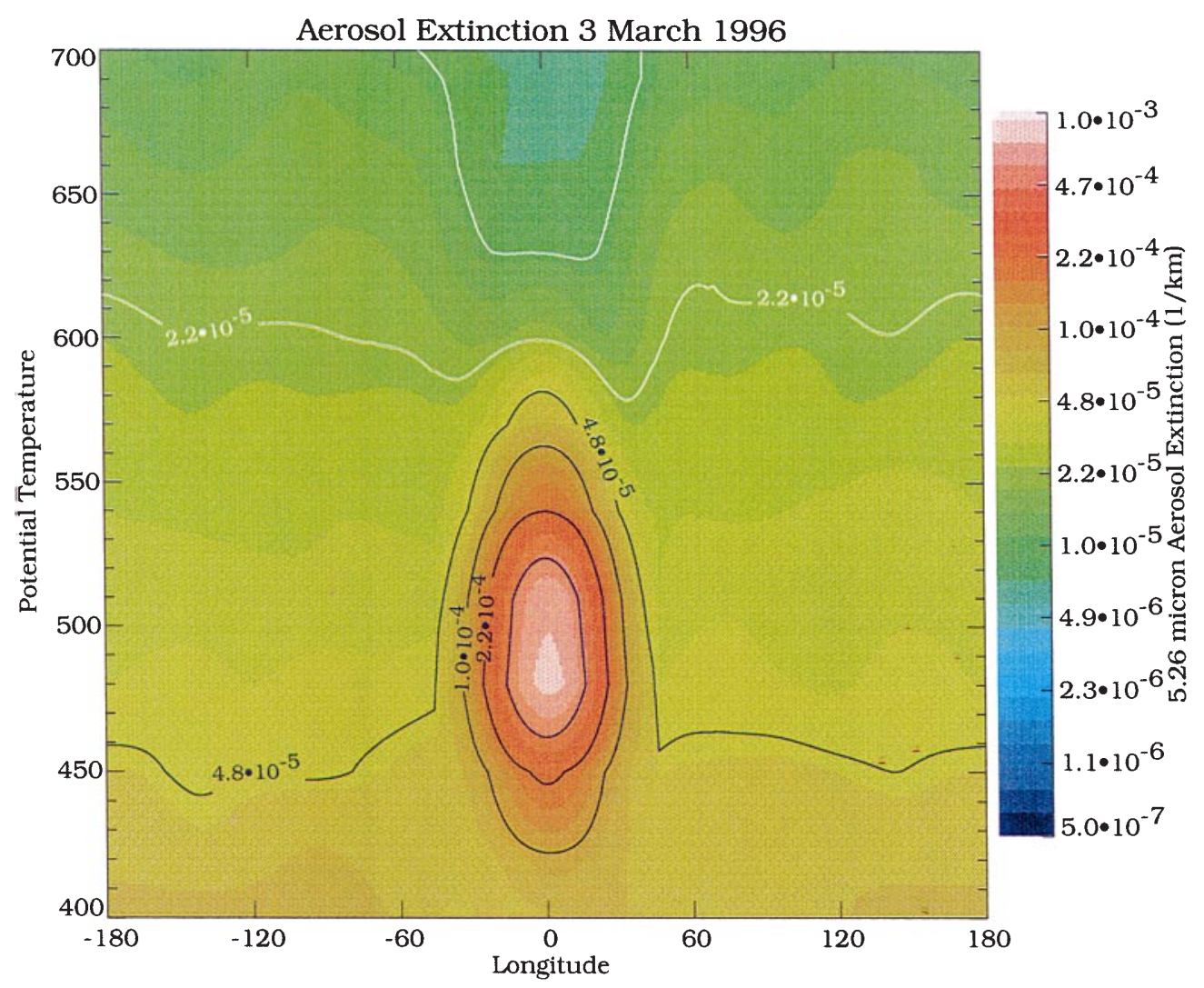

Fig. 19. HALOE measurements of aerosol extinction $(5.26 \mu \mathrm{m})$ in $\mathrm{km}^{-1}$ at $52^{\circ} \mathrm{N}$ on March 3, 1996 
sphere, despite strong variations caused by dynamical processes. Severe chemical ozone column loss of 120 160 Dobson units is derived for this period (see also, Müller et al., 1997a). Here, we have considered further aspects of the HALOE observations in the Arctic over this period. It was demonstrated that the November 1995 HALOE observations may be used as a reference for the chemically unperturbed conditions inside the incipient vortex. Further, it was shown that the reason for the observed increase in the calculated column ozone losses when V18 data are used instead of V17 (Müller et al., 1996, 1997a), could be understood as the effect of a combination of several smaller changes. Finally, it was concluded that there is good agreement between the relevant HALOE measurements in the Arctic in winter and spring 1995-96 with observations by other groundbased and satellite instruments.

Acknowledgements. A lot of the material presented here was first assembled as a reply to a review by Ross Salawitch of an earlier paper (Müller et al., 1997a); we thank him for his thoughtful review. Further, we are grateful to G.Manney for helpful comments. We thank the HALOE team at NASA Langley for providing the HALOE data, which made this study possible. We also thank G.Manney and D.Donovan for providing unpublished ozone data, as well as the UKMO and the ECMWF for meteorological analyses. We thank Guy Beaver for helpful comments on HALOE data versions and Kai-Uwe Eichmann for help with the analysis of the GOME data. This work was supported in part by the German Bundesministerium für Bildung, Wissenschaft, Forschung und Technologie.

\section{References}

Abrams, M. C., et al., Trace gas transport in the Arctic vortex inferred from ATMOS ATLAS-3 observations during April 1993, Geophys. Res. Lett., 23, 2345-2348, 1996.

Bojkov, R. D., V. E. Fioletov, D. S. Balis, C. S. Zerefos, T. V. Kadygrova, and A. M. Shalamjansky, Further ozone decline during the Northern Hemisphere winter-spring of 1994-1995 and the new record low over Siberia, Geophys. Res. Lett., 22, 2729-2732, 1995 .

Bojkov, R. D., D. S. Balis, C. S. Zerefos, and K. Tourpali, Northern Hemisphere winter-spring ozone changes in 1990-1996, Proc. XVIII Quad. Ozone Symp., L'Aquila, 251-254, 1998.

Browell, E. V., C. F. Butler, M. A. Fenn, W. B. Grant, S. I. Ismail, M. R. Schoeberl, O. B. Toon, M. Loewenstein, and J. R. Podolske, Ozone and aerosol changes during the 1991-1992 airborne Arctic stratospheric expedition, Science, 261, 11551158, 1993.

Burrows J. P., et al., "GOME Interim Report”, ESA SP1151, 1993.

Coy, L., R. R. Nash, and P. A. Newman, Meteorology of the polar vortex: Spring 1997, Geophys. Res. Lett., 24, 2693-2696, 1997.

Donovan, D. P., J. C. Bird, J. A. Whiteway, T. J. Duck, S. R. Pal, and A. I. Carswell, Lidar observations of stratospheric ozone and aerosol above the Canadian high Arctic during the 1994-95 winter, Geophys. Res. Lett., 22, 3489-3492, 1995.

Donovan, D. P., J. C. Bird, J. A. Whiteway, T. J. Duck, S. R. Pal, A. I. Carswell, J. W. Sandilands and J. W. Kaminski, Ozone and aerosol observed by Lidar in the Canadian Arctic during the winter of 1995/96, Geophys. Res. Lett., 23, 3317-3320, 1996.

Donovan, D. P., et al., Ozone, column $\mathrm{ClO}$, and PSC measurements made at NDSC Eureka observatory $\left(80^{\circ} \mathrm{N}, 86^{\circ} \mathrm{W}\right)$ during the spring of 1997, Geophys. Res. Lett., 24, 2709-2712, 1997.

Douglass, A. R., M. R. Schoeberl, R. S. Stolarski, J. W. Waters, J. M. Russell, A. E. Roche, and S. T. Massie, Interhemi- spheric differences in springtime production of $\mathrm{HCl}$ and $\mathrm{ClONO}_{2}$ in the polar vortices, J. Geophys. Res., 100, $13967-$ 13978, 1995.

Dobson, G. M. B., D. N. Harrison, and J. Lawrence, Measurements of the amount of ozone in the earth's atmosphere and its relation to other geophysical conditions: Part III, Proc. R. Soc., A122, 456-486, 1929.

Eisinger, M., A. Richter, A. Ladstätter-Weißenmayer, and J. P. Burrows, DOAS zenith sky observations: 1 . BrO measurements over Bremen (53N), 1993-1994, J. Atmos. Chem., 26, 93-108, 1997

Fairlie, T. D. A., R. B. Pierce, W. L. Grose, and G. Lingenfelser, Lagrangian forecasting during ASHOE/MESA: analysis of the predictive skill for analyzed and reverse-domain-filled potential vorticity, J. Geophys. Res., 102, 13169-13182, 1997.

von der Gathen, P., et al., Observational evidence for chemical ozone depletion over the Arctic in winter 1991-92, Nature, 375, 131-134, 1995.

Goutail, F., et al., Ozone depletion in the Arctic during the winters of 1993-94 and 1994-95, J. Atmos.Chem., in press, 1998a.

Goutail, F., et al., Total ozone reductions in the Arctic vortex during the winters of 1995/96 and 1996/97, Proc. Fourth Europ. Symp. Polar Strat. Ozone, Schliersee, in press, 1998b.

Geophys. Res. Lett., Special section on Arctic ozone loss in 199697, Nov. 15., 1997.

Hansen, G., and U.-P. Hoppe, Lidar observations of polar stratospheric clouds and stratospheric temperature in winter 1996/96 over northern Norway, Geophys. Res. Lett., 23, 131134, 1996.

Hansen, G., T. Svenøe, M. Chipperfield, A. Dahlback, and U.-P. Hoppe, Evidence of substantial ozone depletion in winter 1996/ 96 over northern Norway, Geophys. Res. Lett., 24, 799-802, 1997.

Hintsa, E. J., et al., Dehydration and denitrification in the Arctic polar vortex during the 1995-1996 winter, Geophys. Res. Lett., 25, 501-504, 1998.

Hofmann, D. J., and T. L. Deshler, Evidence from balloon measurements for chemical depletion of stratospheric ozone in the Arctic winter of 1989-90, Nature, 349, 300-305, 1991.

Hofmann, D. J., T. L. Deshler, P. Aimedieu, W. A. Matthews, P. V. Johnston, Y. Kondo, W. R. Sheldon, G. J. Byrne, and J. R. Benbrook, Stratospheric clouds and ozone depletion in the Arctic during January 1989, Nature, 340, 117-121, 1989.

Koike, M., Y. Kondo, M. Hayashi, Y. Iwasaka, P. A. Newman, M. Helten, and P. Aimedieu, Depletion of Arctic ozone in the winter 1990, Geophys. Res. Lett., 18, 791-794, 1991.

Kyrö, E., et al., Analysis of the ozone soundings made during the first quarter of 1989 in the Arctic, J. Geophys. Res., 97, 80838091, 1992.

Larsen, N., B. Knudsen, I. S. Mikkelsen, T. S. Jørgensen, and P. Eriksen, Ozone depletion in the Arctic stratosphere in early 1993, Geophys. Res. Lett., 21, 1611-1614, 1994.

Lahoz, W. A., A. O’Neill, A. Heaps, V. D. Pope, R. Swinbank, R. S. Harwood, L. Froidevaux, W. G. Read, J. W. Waters, and G. E. Peckham, Vortex dynamics and the evolution of water vapour in the stratosphere of the southern hemisphere. $Q$. J. R. Meteorol. Soc., 122, 423-450, 1996.

Manney, G. L., et al., Chemical depletion of ozone in the Arctic lower stratosphere during winter 1992-93, Nature, 370, 429434, 1994a.

Manney, G. L., R. W. Zurek, A. O.'Neill, and R. Swinbank, On the motion of air through the stratospheric polar vortex, J. Atmos. Sci., 51, 2973-2994, 1994b.

Manney, G. L., L. Froidevaux, J. Waters, M. L. Santee, W. G. Read, D. A. Flower, R. F. Jarnot, and R. W. Zurek, Arctic ozone depletion observed by UARS MLS during the 1994-95 winter, Geophys. Res. Lett., 23, 85-88, 1996 a.

Manney, G. L., M. L. Santee, L. Froidevaux, J. Waters, and R. W. Zurek, Polar vortex conditions during the 1995-96 Arctic winter: meteorology and MLS ozone, Geophys. Res. Lett., 23, 3203-3206, 1996b. 
Manney, G. L., L. Froidevaux, M. L. Santee, R. W. Zurek, and J. Waters, MLS observations of Arctic ozone loss in 1996-97, Geophys. Res. Lett., 24, 2697-2700, 1997.

McKenna, D. S., R. L. Jones, J. Austin, E. V. Browell, M. P. McCormick, A. J. Krueger, and A.F. Tuck, Diagnostic studies of the Antarctic vortex during the 1987 Antarctic ozone experiment: ozone miniholes, J. Geophys. Res., 94, 11641-11668, 1989.

Moseley H., and R. M. MacKie, Ultraviolet B radiation was increased at ground level in Scotland during a period of ozone depletion, Br. J. Dermatol., 137, 101-102, 1997.

Müller, R., T. Peter, P. J. Crutzen, H. Oelhaf, G. P. Adrian, T. v. Clarmann, A. Wegner, U. Schmidt, and D. Lary, Chlorine chemistry and the potential for ozone depletion in the Arctic stratosphere in the winter of 1991/92, Geophys. Res. Lett., 21, 1427-1430, 1994.

Müller, R., P. J. Crutzen, J. -U. Grooß, C. Brühl, J. M. Russell III, and A. F. Tuck, Chlorine activation and ozone depletion in the Arctic vortex: observations by HALOE on UARS, J. Geophys. Res., 101, 12531-12554, 1996.

Müller, R., P. J. Crutzen, J. -U. Grooß, C. Brühl, J. M. Russell III, H. Gernandt, D. S. McKenna, and A. F. Tuck, Severe chemical ozone loss in the Arctic during the winter of 1995-96, Nature, 389, 709-712, 1997a.

Müller, R., J.-U. Grooß, D. S. McKenna, P. J. Crutzen, C. Brühl, J. M. Russell III, and A. F. Tuck, HALOE observations of the vertical structure of chemical ozone depletion in the Arctic vortex during winter and early spring 1996-1997, Geophys. Res. Lett., 24, 2717-2720, 1997b.

Nash, E. R. P. A. Newman, J. E. Rosenfield, and M. R. Schoeberl, An objective determination of the polar vortex using Ertel's potential vorticity, J. Geophys. Res., 101, 9471-9478, 1996.

Naujokat, B., and S. Pawson, The cold stratospheric winters 1994/ 1995 and 1995/1996, Geophys. Res. Lett., 23, 3703-3706, 1996.

Newman, P. A., J. F. Gleason, R. D. McPeters, and R. S. Stolarski, Anomalously low ozone over the Arctic, Geophys. Res. Lett., 24, 2689-2692, 1997.

Plumb, R. A., and M. W. K. Ko, Interrelationships between mixing ratios of long-lived stratospheric constituents, J. Geophys. Res., 97, 10,145-10,156, 1992.

Proffitt, M. H., J. J. Margitan, K. K. Kelly, M. Loewenstein, J. R. Podolske, and K. R. Chan, Ozone loss in the Arctic polar vortex inferred from high-altitude aircraft measurements, Nature, 347, 31-36, 1990.

Proffitt, M. H., K. Aikin, J. J. Margitan, M. Loewenstein, J. R. Podolske A. Weaver, K. R. Chan, H. Fast, and J. W. Elkins,
Ozone loss inside the northern polar vortex during the 19911992 winter, Science, 261, 1150-1154, 1993.

Rex, M., et al., Prolonged stratospheric ozone loss in the 1995-96 Arctic winter, Nature, 389, 835-837, 1997.

Rex, M., et al., In situ measurements of stratospheric ozone depletion rates in the Arctic winter 1991/1992: a Lagrangian approach, J. Geophys. Res., 103, 5843-5854, 1998a.

Rex, M., et al., Chemical ozone loss in the Arctic winter 1994/95 as determined by the Match technique, J. Atmos. Chem., in press, 1998b.

Rosenfield, J. E., P. A. Newman, and M. R. Schoeberl, Computations of diabatic descent in the stratospheric polar vortex, $J$. Geophys. Res., 99, 16677-16689, 1994.

Rummukainen M., B. Knudsen, and P. von der Gathen, Dynamical diagnostics of the edges of the polar vortices, Ann. Geophysicae, 12, 1114-1118, 1994.

Russell, J. M., III, L. L. Gordley, J. H. Park, S. R. Drayson, A. F. Tuck, J. E. Harries, R. J. Cicerone, P. J. Crutzen, and J. E. Frederick, The Halogen Occultation Experiment, J. Geophys. Res., 98, 10777-10797, 1993.

Santee, M. L., G. L. Manney, L. Froidevaux, and J. Waters, Polar vortex conditions during the 1995-96 Arctic winter: MLS ClO and $\mathrm{HNO}_{3}$, Geophys. Res. Lett., 23, 3207-3210, 1996a.

Santee, M. L., L. Froidevaux, G. L. Manney, W. G. Read, J. Waters, M. P. Chipperfield, A. E. Roche, J. B. Kumer, J. L. Mergenthaler, and J. M. III, Russell, Chlorine decativation in the lower stratospheric polar regions during late winter: results from UARS, J. Geophys. Res., 101, 18835-18859, 1996b.

Seckmeyer, G., B. Mayer, G. Bernhard, R. Erb, A. Albold, H. Jäger, and W.R. Stockwell, New maximum UV irradiance levels observed in central Europe, Atmos. Envir. 31, 2971-2976, 1997.

Tuck, A. F., and M. Proffitt, Comment on "On the magnitude of transport out of the Antarctic polar vortex" by Wauben et al., J. Geophys. Res., in press, 1998.

Vömel, H., M. Rummukainen, R. Kivi, J. Karhu, T. Turunen, E. Kyrö, J. Rosen, N. Kjome, and S. Oltmans, Dehydration and sedimentation of ice particles in the Arctic stratospheric vortex, Geophys. Res. Lett., 24, 795-798, 1997.

Wirth M., and W. Renger, Evidence of large-scale ozone depletion within the arctic polar vortex $94 / 95$ based on airborne LIDAR measurements, Geophys. Res. Lett, 23, 813-816, 1996.

Wirth M., G. Ehret, P. Mörl, and W. Renger, Two dimensional stratospheric aerosol distributions during EASOE, Geophys. Res. Lett, 21, 1287-1290, 1994. 